University of South Carolina

Scholar Commons

Theses and Dissertations

Summer 2019

\title{
3-D Potential Field Inversion Camp Clubhouse Crossroads Mafic Intrusive Pluton, Coastal Plain, South Carolina
}

Kubra Sibel Albayrak

Follow this and additional works at: https://scholarcommons.sc.edu/etd

Part of the Geology Commons

Recommended Citation

Albayrak, K. S.(2019). 3-D Potential Field Inversion Camp Clubhouse Crossroads Mafic Intrusive Pluton, Coastal Plain, South Carolina. (Master's thesis). Retrieved from https://scholarcommons.sc.edu/etd/5357

This Open Access Thesis is brought to you by Scholar Commons. It has been accepted for inclusion in Theses and Dissertations by an authorized administrator of Scholar Commons. For more information, please contact digres@mailbox.sc.edu. 


\title{
3-D POTENTIAL FIELD INVERSION CAMP CLUBHOUSE CROSSROADS MAFIC INTRUSIVE PLUTON, COASTAL PLAIN, SOUTH CAROLINA
}

by

\author{
Kubra Sibel Albayrak \\ Bachelor of Science \\ Sakarya University, 2012
}
Submitted in Partial Fulfillment of the Requirements
For the Degree of Master of Science in
Geological Sciences
College of Arts and Sciences
University of South Carolina
2019
Accepted by:
James Kellogg, Director of Thesis
Michael Bizimis, Reader
Camelia Knapp, Reader

Cheryl L. Addy, Vice Provost and Dean of the Graduate School 
(C) Copyright by Kubra Sibel Albayrak, 2019 All Rights Reserved. 


\section{DEDICATION}

This thesis is dedicated to my sweet son, Allen Rumi, welcome to our world. 


\section{ACKNOWLEDGEMENTS}

This thesis would not have been possible without the support of my mentors,

family, and friends. My deepest appreciation and gratitude for the help and support are extended to the following persons who have contributed to making this thesis possible.

Dr. James Kellogg, my advisor, his guidance, patience, and support have benefitted me to become a better researcher. I also would like to acknowledge my committee members, Drs. Camelia Knapp, and Michael Bizimis, for their guidance, to make this thesis better. I especially appreciate the Turkish Petroleum Corporation, without their full fellowship, I would not have this opportunity. I would also thank Geosoft Inc. for the software donation with Academic Licenses for Oasis Montaj, and GM-SYS 2D and 3D. My lab mates, Saad Alarifi, and Essam Saeid, thank you for always being so encouraging and helping me whenever needed. Thanks to the Andean Geophysical Laboratory for the support of the computer and research environment.

I also owe many thanks to my family and friends, their unconditional support, which helped me through all the difficulties. Greysi Irdam, my US family, who have always cheered me through all the hardship. I thank my mother, Aysel, my father, Salih, and my brother, Bilal, for always sending their love and encouragement from distance. Lastly, I thank my husband, Rustem Fatih, for encouraging me in every step of my life. 


\begin{abstract}
The Central Atlantic Magmatic Province (CAMP) at the Triassic-Jurassic boundary, is the largest known igneous province in the world. However, the geometry and volume of CAMP intrusives under the Coastal Plain of the southeastern United States are poorly known. Under the Coastal Plain sediments of Georgia and South Carolina, the "J" seismic reflector was predicted to be produced by a CAMP lava flow. Recent studies of seismic and well data have shown that the "J" reflector is an unconformity and only locally a CAMP lava flow. In the Clubhouse Crossroads area of South Carolina, seismic reflection, seismic refraction, and well data are available to constrain the shallow structure under the Coastal Plain sediments but have not succeeded in imaging the underlying pluton. We take advantage of a rich potential field dataset to predict the deeper structure of the CAMP mafic intrusive pluton at Clubhouse Crossroads for the first time. The CAMP plutons have both very high densities as well as high magnetic susceptibilities, which makes them ideal for 3-D inversion techniques. We forward modeled the shallow structure with seismic and well control and then inverted for the shape of the deeper structures assuming realistic densities and magnetic properties. The inversion methods used include Fast-Fourier Transform inversion with GMSYS 3D, gravity Fourier Matlab depth inversion, and Oasis Montaj-Voxi earth modeling inversion. The resulting 3-D models show that the Clubhouse Crossroads mafic intrusive is a diabase/gabbro CAMP age laccolith fed by two deep conduits. The laccolith is up to $2 \mathrm{~km}$ thick and extends from 1 to $3 \mathrm{~km}$ depth over an area of $1900 \mathrm{~km}^{2}$. The volume of the
\end{abstract}


Clubhouse Crossroads laccolith is $1300 \mathrm{~km}^{3}$ or over eight times larger than the Palisades Sill in the Newark Basin. Previous estimates of the Clubhouse Crossroads volumes based solely on drilling and seismic reflection may greatly underestimate the total volumes of CAMP preserved under the Coastal Plain. CAMP laccoliths and basalts under the Coastal Plain may form self-sealing storage reservoirs for $\mathrm{CO}^{2}$ sequestration by injection wells. 


\section{TABLE OF CONTENTS}

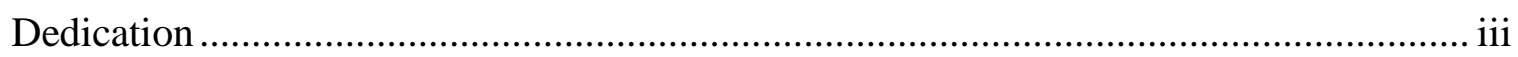

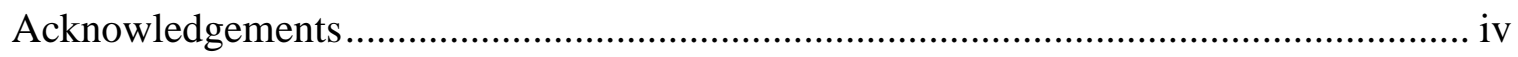

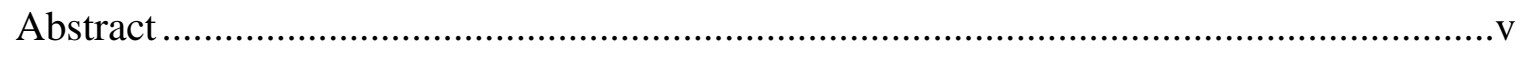

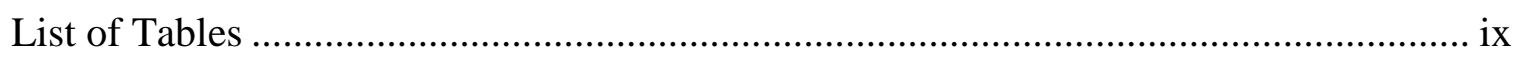

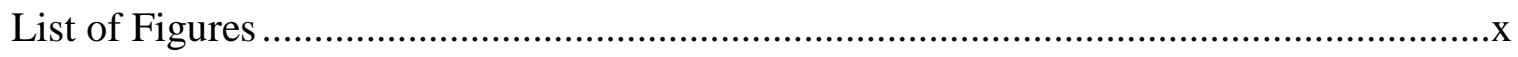

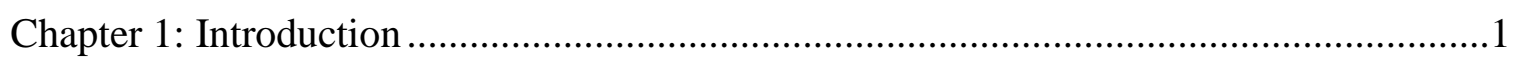

1.1: Central Atlantic Magmatic Province .........................................................

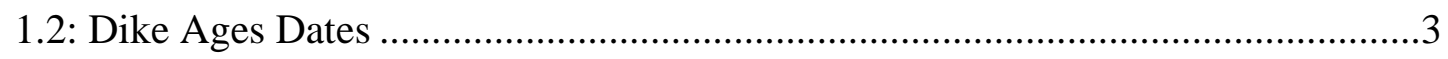

1.3: Clubhouse Crossroads Age Dates .............................................................

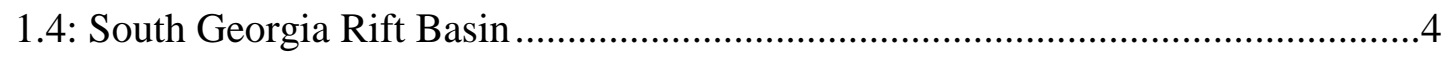

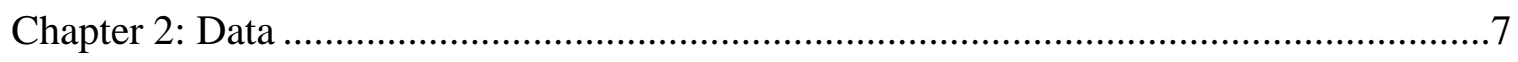

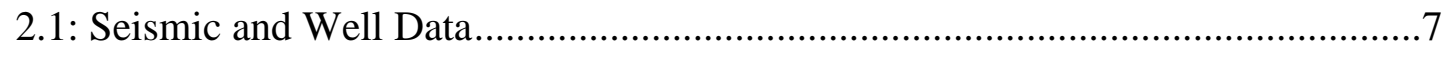

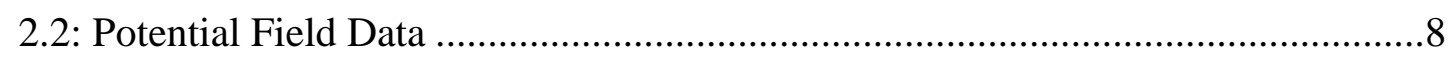

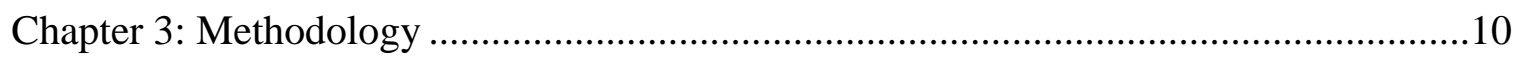

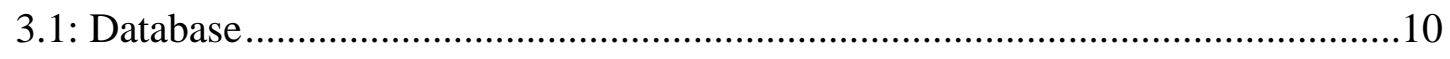

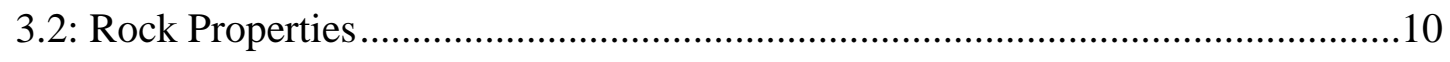

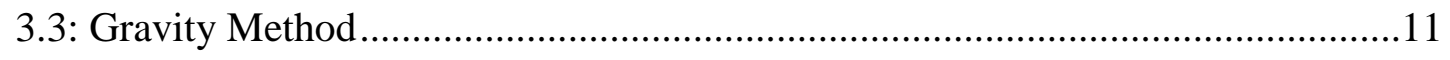

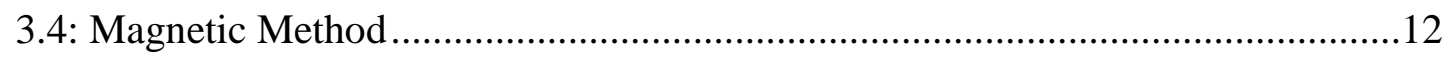

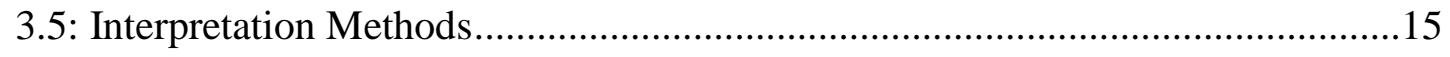

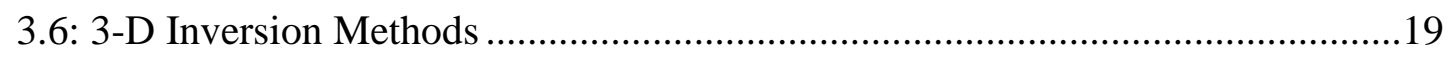


Chapter 4: Results and Conclusions

4.1: Magnetic Results. .24

4.2: 2-D Forward Modeling of Potential Field Data......

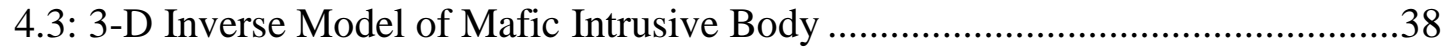

4.4: Is the Clubhouse Crossroads mafic intrusive a laccolith or a mafic sill?

4.5: Volume Estimation and Density Uncertainties.

References.. .50 


\section{LIST OF TABLES}

Table 3.1 Magnetic susceptibilities of various rocks and minerals ................................13

Table 4.1 Densities Used in Forward Modelling ........................................................29

Table 4.2 Densities Used for Basalt, Diabase, and Gabbro ............................................30

Table 4.3 Magnetic Susceptibilities Used in Forward Modelling ..................................31 


\section{LIST OF FIGURES}

Figure 1.1 Map of the southeastern North American CAMP diabase dike swarm.............2

Figure 1.2 CAMP geodynamic schematic model ....................................................

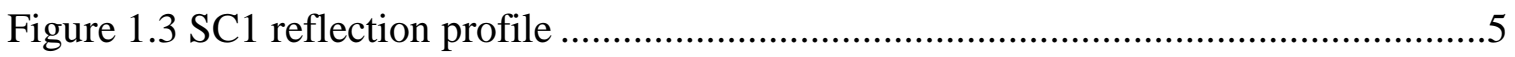

Figure 1.4 Map of South Georgia Rift (SGR) ............................................................

Figure 1.5 A: Distribution of dikes and flows of Central Atlantic magmatic province.......6

Figure 1.5 B: Distribution of Mesozoic basaltic dikes, sills, and flows ..........................6

Figure 2.1 The map of SGR (Left). Zoomed in map of the study area (Right).................7

Figure 2.2 A: Portion of stacked seismic line data in two-way travel time (TWTT).........8

Figure 2.2 B: Penetration of Coastal plain, Triassic, and Jurassic basalt and diabase.........8

Figure 2.3 Bouguer gravity map (left) and aeromagnetic map (right)...........................

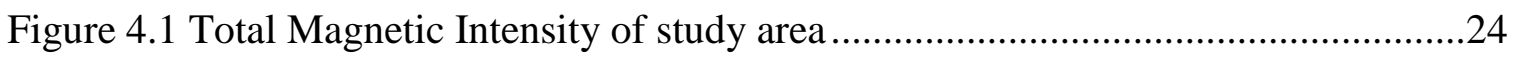

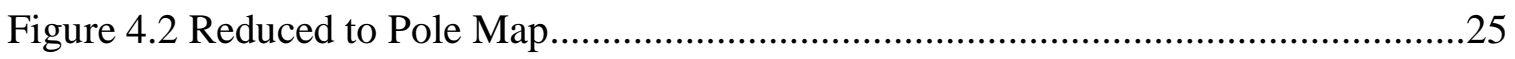

Figure 4.3 Analytic Signal of the Total Magnetic Intensity Map .................................26

Figure 4.4 Tilt derivative of the reduce to the pole magnetic anomalies........................27

Figure 4.5 Forward model profile locations on the Total Magnetic Intensity Map..........28

Figure 4.6 Forward model profiles located on the Gravity Map ................................28

Figure 4.7 Magnetic Map of South Carolina showing Clubhouse Crossroads mafics. .....32 
Figure 4.8 Along part of SEISDATA 4 seismic profile

Figure 4.9 Seisdata 4 Profile 1 crossing Clubhouse Crossroads.... .33

Figure 4.10 Profile 2 of Camp Mafics 35

Figure 4.11 Profile 3 of Camp mafics 36

Figure 4.12 Profile 4 of Camp Mafics 37

Figure 4.13 Upper and lower bounds of the Coastal Plain sediment layer 38

Figure 4.14 Inverted gravity for the top of mafic intrusive 39

Figure 4.15 Location map of 3-D Gravity Matlab inversion profiles

Figure 4.16 3-D inverse model (above) predicts up to $2 \mathrm{~km}$ thick source geometry .........40

Figure 4.17 3-D Gravity-Fourier Matlab depth inversion

Figure 4.18 Voxi Earth Modeling. .42

Figure 4.19 Schematic image of Laccolith (above) and mafic sills (below) .43

Figure 4.20 The extent of CAMP mafic bodies along the 2-D forward model profiles ....45

Figure 4.21 Lateral Extent of Clubhouse Crossroads Basalt .46

Figure 4.22 Refraction and reflection velocities in the Summerville area .47

Figure 4.23 Nafe and Drake Velocity to Density Curve. .48 


\section{CHAPTER 1}

\section{INTRODUCTION}

Central Atlantic Magmatic Province (CAMP) is the largest known igneous province in the world. However, geometry and volume of CAMP intrusives in the SE US under the Coastal Plain are poorly known. Clubhouse Crossroads basalts have been sampled by drilling, but seismic reflection and refraction have not succeeded in imaging the deeper pluton. This study takes advantage of a rich potential field dataset and the high densities and magnetic susceptibilities of the mafic rocks to model the deep structure of the pluton for the first time.

\subsection{The Central Atlantic Magmatic Province}

At the end of the Triassic, within $\sim 1$ m.y. of $200 \mathrm{Ma}$, the Central Atlantic Magmatic Province (CAMP) formed as the largest continental igneous province in the world (Fig. 1) just before Pangea broke up. CAMP spans four continents and covers an estimated area of 7-10 $\times 10^{6} \mathrm{~km}^{2}$ (Marzoli et al., 1999; McHone, 2000). The massive CAMP tholeiitic basalts flows have been associated with Triassic-Jurassic mass extinctions. Widespread magmatism occurred up to $2000 \mathrm{~km}$ from the continental margins. Geochemical signatures of CAMP suggest an upper mantle source modified by subduction processes, and different subduction-related signatures were recognized in the mantle source of the northern versus southern CAMP lavas (Whalen et al., 2015). CAMP 
Rocks are found in buried rift basins, including the South Georgia Rift (SGR)

Basin (Daniels et al., 1983; McBride et al., 1989). The basaltic magmatism produced dikes flows, and sills all along the eastern North American rifted margin.

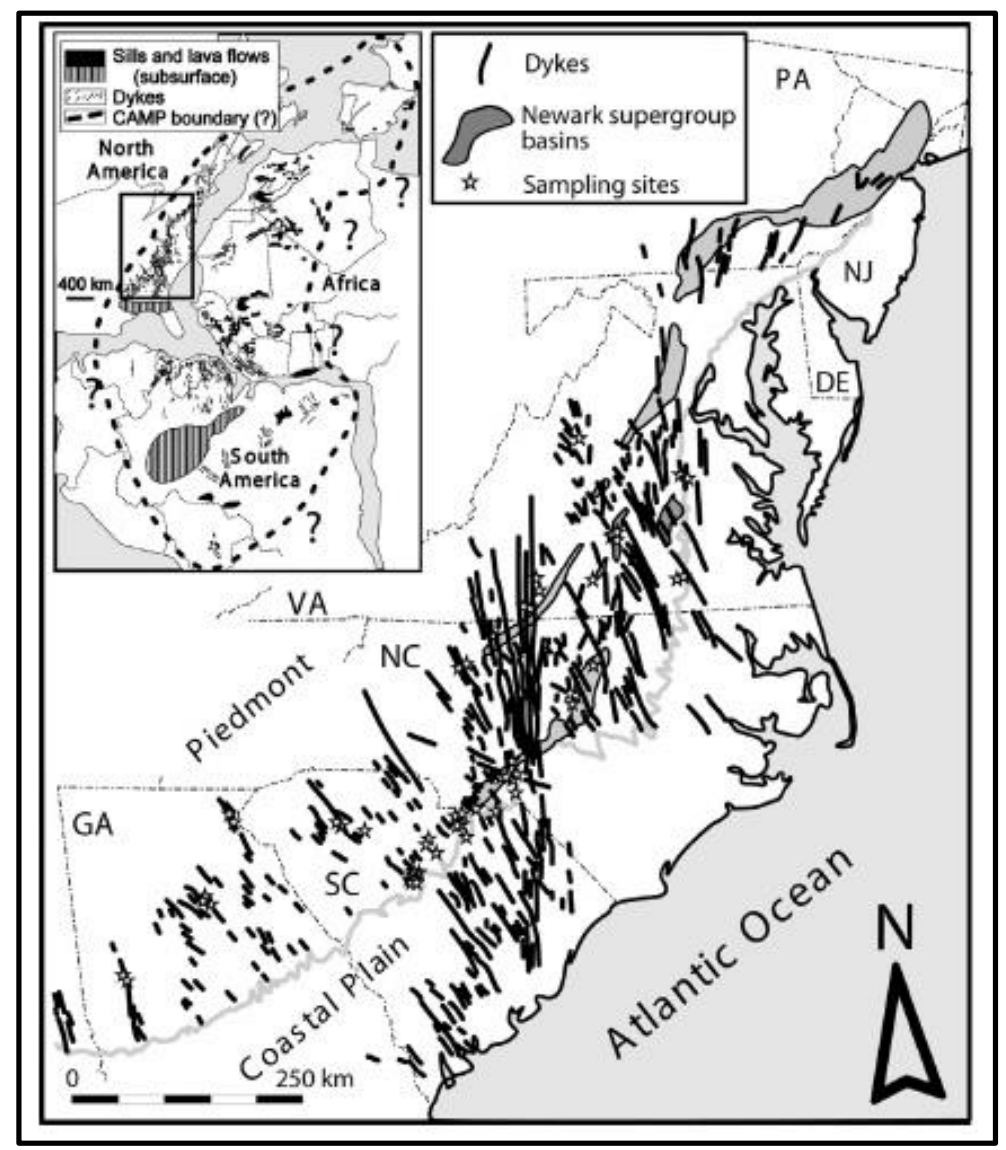

Figure 1.1 Map of the southeastern North American CAMP diabase dike swarm (Ragland et al., 1983) based on the aeromagnetic mapping. Triassic rift basins of the Newark Supergroup are outlined as grey areas. U.S.A. state acronyms are as follows: GA Georgia, SC SouthCarolina, NC NorthCarolina, VA Virginia, DE Delaware, NJ NewJersey, and PA Pennsylvania. (modified after Marzoli et al., 2011; Callegaro, and others, 2013)

The distribution and timing of this magmatism and the absence of regional uplift or a single identifiable hotspot track suggest strong lithospheric control on the origin of 
the Central Atlantic Magmatic Province (e.g., Hames et al., 2000, Figure 1.2), although a broad Western Pacific Cretaceous super swell-style origin cannot be completely ruled

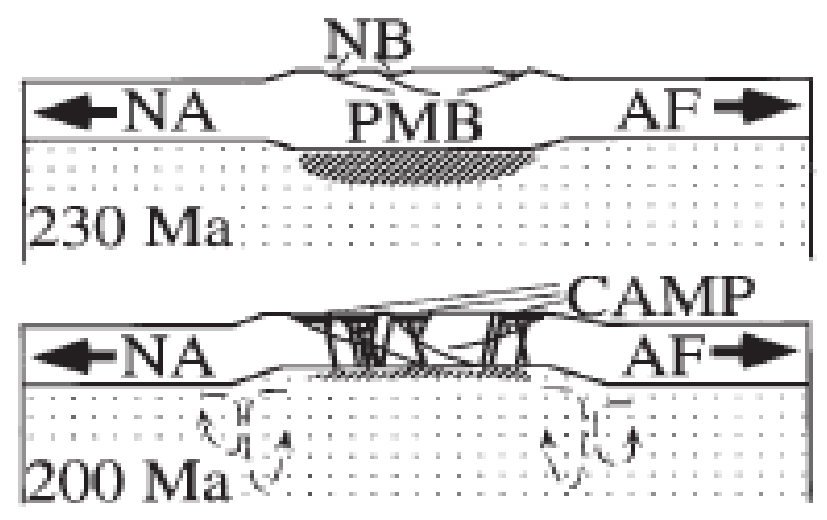

out.

Figure 1.2 CAMP geodynamic schematic model (Hames et al.,2000). The upper model illustrates magmas being produced by lithosphere-mantle interaction at $230 \mathrm{Ma}$. The lower model shows melting and magma emplacement ca. 200 Ma, North America (NA), Africa (AF), and CAMP.

\subsection{Dike Age Dates}

There are three major directional groups (Beutel et al., 2005): northwest trending dikes, north to the north-northwest trending, and minor northeast trending dikes (Figure 1.1). Dikes with all three trends were emplaced within a 2 Ma period (c.a. 199-197 Ma) and may represent a rapidly changing stress field (Beutel et al., 2005). Dikes in the southeastern United States represent a major component of the Central Atlantic Magmatic Province and may record early kinematics of Pangean breakup. ${ }^{40} \mathrm{Ar} /{ }^{39} \mathrm{Ar}$ and $\mathrm{U} / \mathrm{Pb}$ ages were used to date extensive basaltic magmatism in northernmost South America at $200 \pm 4 \mathrm{Ma}$ (Beutel et al., 2005). The magmatism coincided closely in time with a major mass extinction at the Triassic-Jurassic boundary. Geochronological and 
paleomagnetic data constrain the CAMP age range between $~ 191$ and 205 Ma with most of this widespread magmatism peaking at $200 \mathrm{Ma}$.

\subsection{Clubhouse Crossroads Age Dates}

CAMP ages vary from 204 Ma to 190 Ma (Nomade et al., 2005). Clubhouse Crossroads Ar-Ar ages vary from 204 Ma to 162 Ma (Lanphere et al., 1983; Gottfried et al., 1983) although Hames et al. (2010) found 172 Ma to 169 Ma. However, there are no ages for the diabase or gabbro intrusive. In South Georgia, diabase from four wells are dated from $182 \pm$ to $209 \pm 14 \mathrm{Ma}$, which is within the range of dates reported for diabase in the Newark-Gettysburg basin (Chowns and Williams, 1983).

\subsection{South Georgia Rift Basin}

The South Georgia basin is the southernmost and largest early Mesozoic rift basin of the eastern margin of North America. Early Mesozoic rift-basin formation along the eastern margin of North America typically involved igneous activity emplaced as diabase dikes, sills, and basalt flows in sedimentary groups (Olsen, 1997). Rifting and the depositional history of Mesozoic rift basins after Olsen (1997) in Whalen et al. (2015) proposes that synrift CAMP flows are absent from the southern rift basins, but age constraints for basin fill rely on biostratigraphy, paleomagnetic data, and Milankovitch cyclicity and are poorly constrained (Olsen, 1997). It has long been assumed that the largest of the CAMP flows was preserved in the South Georgia Rift as the prominent "J" reflector at the base of the Atlantic coastal plain (Figure 1.3). The "J" reflector/horizon was named by Schilt and others (1983) and has been correlated with a series of tholeiitic basalt flows encountered in the Clubhouse Crossroads drill holes (Gottfried and others, 1983). Recent work by Heffner et al. (2012), however, showed that most wells 
penetrating the reflector did not encounter basalt, but rather an impedance contrast at the base of the Coastal Plain sediments (Figure 1.4). Numerous wells did, however, encounter diabase. The rich spatial gravity and magnetics data coverage reveal widespread sills, dikes, and deep conduits or plutons buried in the South Georgia Rift Basin (Chowns and Williams, 1983) that represent major components of the Central Atlantic Magmatic Province (Figure 1.5).

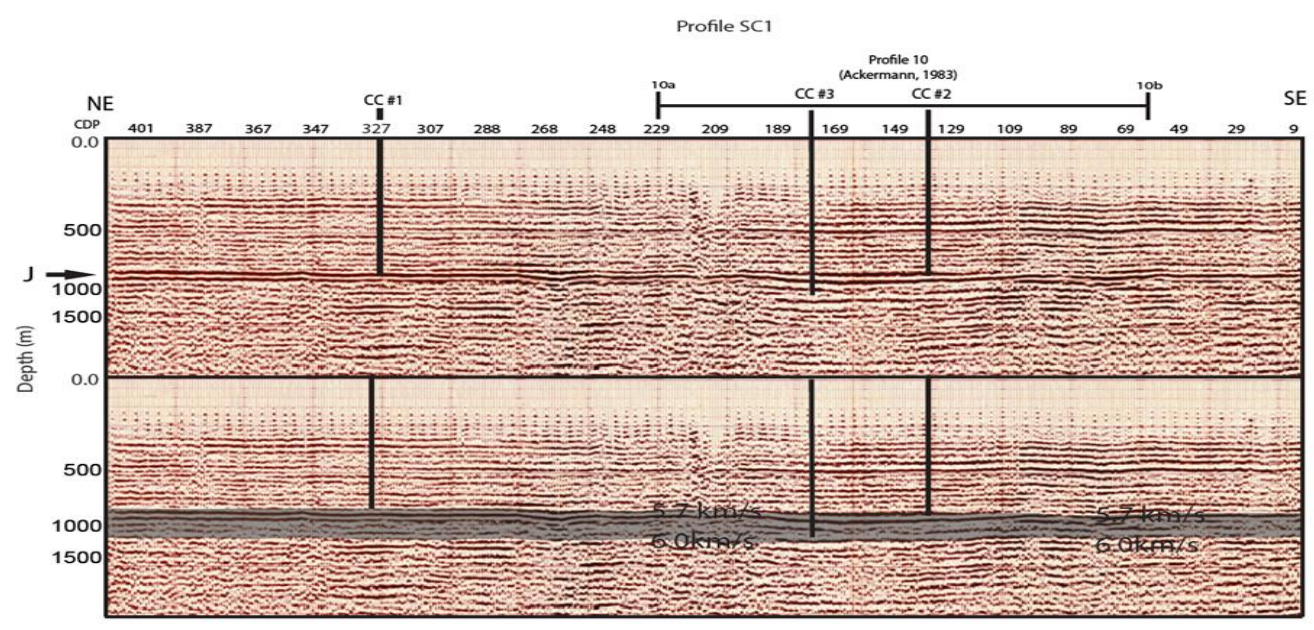

Figure 1.3 SC1 reflection profile un-interpreted (top) and interpreted, which shows J reflector highlighted. Three wells penetrated $750 \mathrm{~m}$ of Coastal Plain sediments. Clubhouse Crossroads (CC) Wells 1 and 2 terminated in basalt/diabase. CC Well 3 terminated in red sedimentary beds. Ackermann's (1983) refraction profile endpoint, CDP numbers between 113 and 60 .

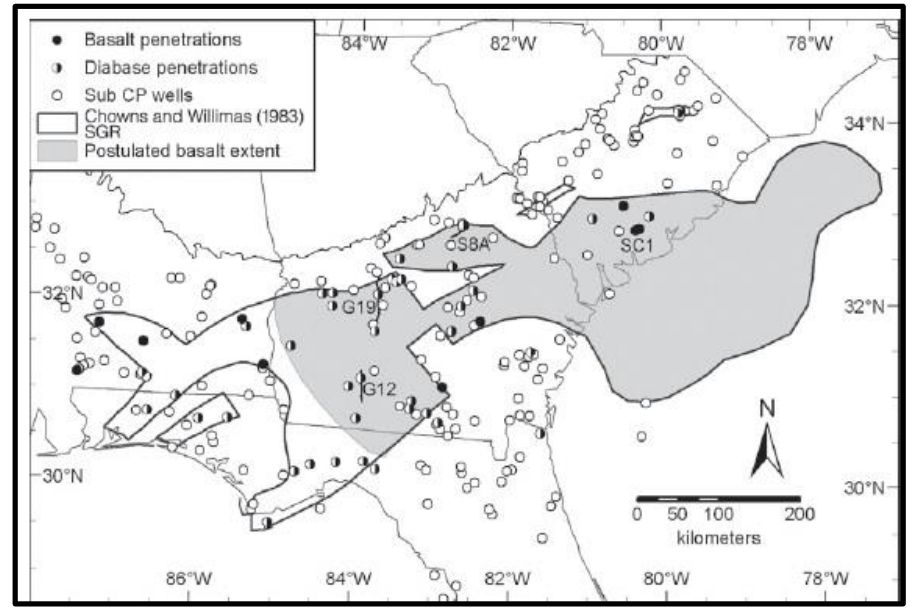

Figure 1.4 Map of South Georgia Rift (SGR) displays postulated flood basalt (shown in gray) and wells that penetrated basalt (filled circles) and diabase (half filled circles). (modified from McBride et al. 1989; Chowns and Williams, 1983). 


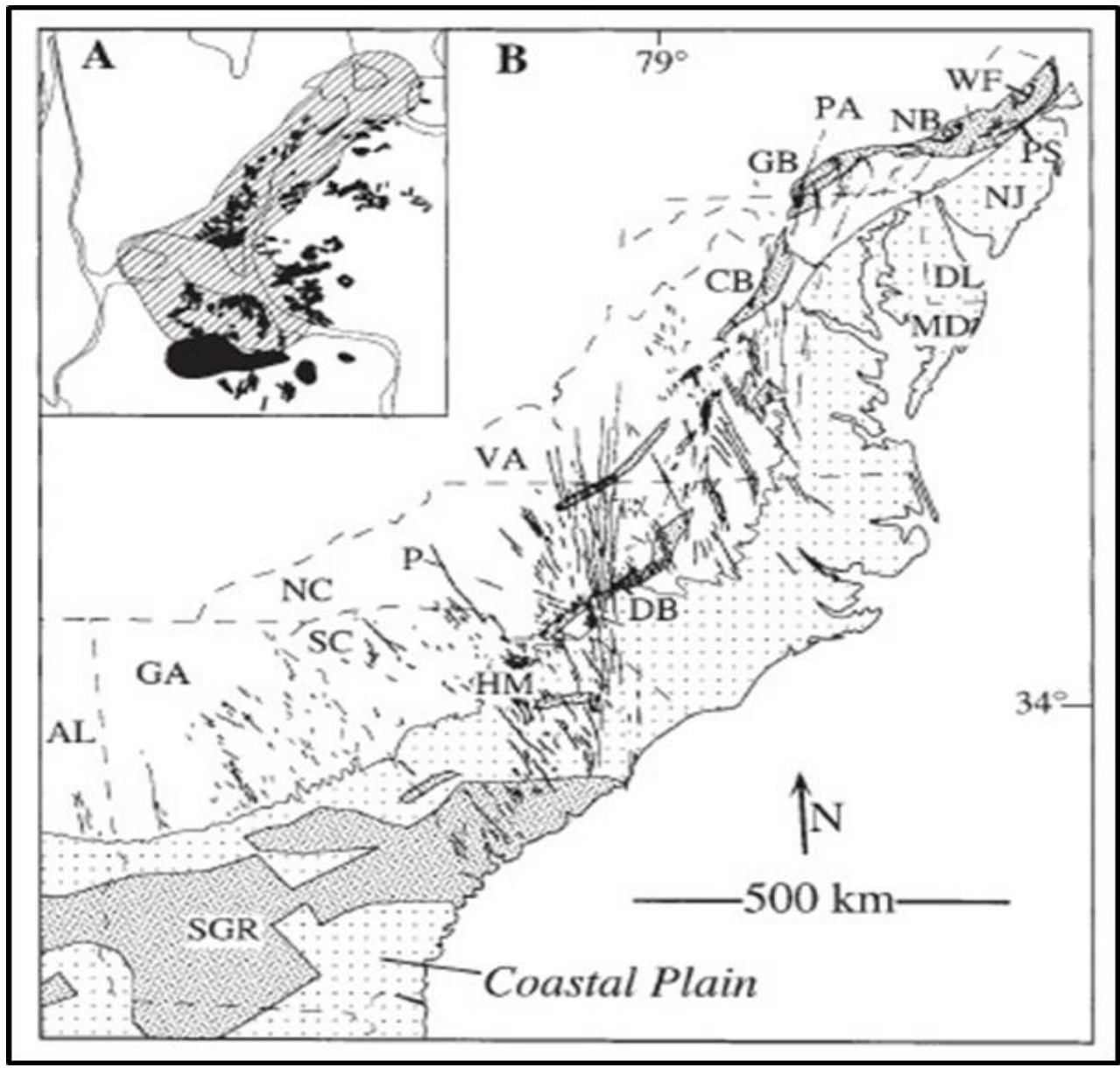

Figure 1.5 A: Distribution of dikes and flows (black) of Central Atlantic magmatic province (May, 1971, with additions from Deckart et al., 1997; Marzoli et al., 1999)B: Distribution of Mesozoic basaltic dikes, sills, and flows of eastern United States and Triassic-Jurassic basins of Newark Supergroup (adapted from Ragland et al., 1983; Chowns and Williams, 1983). Abbreviations: CB Culpeper basin, DB Durham basin, GB Gettysburg basin, HM Haile mine, NB Newark basin, P Pageland dike, PS Palisade sill, SGR South Georgia rift basin, WF Watchung flows 


\section{CHAPTER 2}

\section{DATA}

\subsection{Seismic and Well Data}

Seismic lines and limited good data are available in the study area, most designed to investigate seismicity and faults located near the epicenter of the 1886 Charleston earthquake. In 1975, three Clubhouse Crossroads (CC) wells were drilled 40 km westnorthwest of Charleston, SC by U.S.G.S (Figure 2.1). The Clubhouse Crossroads wells penetrated coastal plain sediments before entering Triassic red beds and tholeiitic basalts. Clubhouse crossroads \#3 well was drilled on the largest positive magnetic anomaly (Figure 2.1,2.2). Seismic data over the Clubhouse Crossroads mafics includes the SEISDATA 4 profile (Figure 4.7).
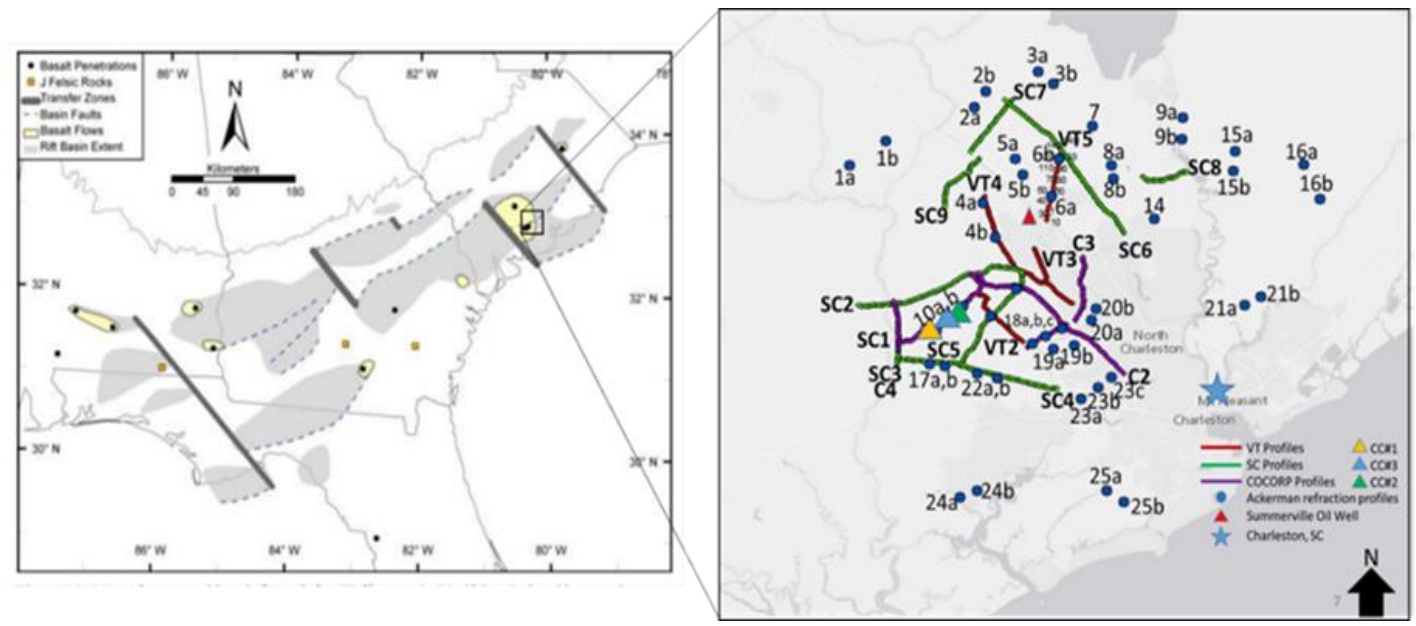

Figure 2.1 Left side shows the map of SGR by Heffner et al. (2013). Right side shows zoomed in map of the study area. The blue star is the location of Charleston, South Carolina. Red lines refer to the Virginia Tech reflection profiles (VT), green lines South Carolina profiles, and purple lines (COCORP). 
Twenty-five seismic refraction profiles were obtained by Ackerman starting in 1975, and four Consortium for Continental Reflection Profiling (COCORP) profiles were collected in 1798 (Figure 2.1). Five reflection profiles were collected by Virginia Tech (VT), and nine seismic reflection profiles being were collected by U.S.G.S (especially refered to as SC1, SC3) (Figure 2.1).

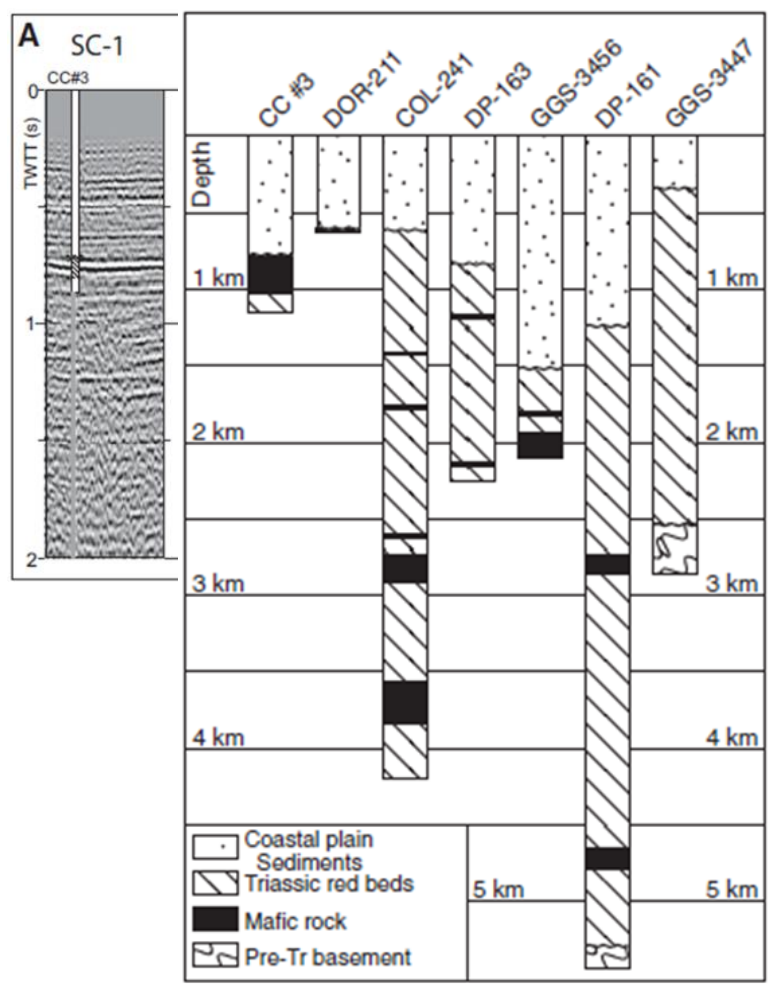

Figure 2.2 A: Portion of stacked seismic line data in two-way traveltime (TWTT) (U.S. Geological Survey SC-1, Chapman and Beale, 2010). B: The selected wells show the penetration of Coastal plain, Triassic (Tr) red beds, and Jurassic basalt and diabase. CC \#3 is Clubhouse Crossroads well \#3.

\subsection{Potential Field Data}

USGS aeromagnetic and land gravity for South Carolina acquired from 1958 to 1978 and regional data acquired from the United States Geological Survey U.S. Gravity Database (and P. Talwani) and the North American Magnetic Map are maintained at the 
University of Texas-El Paso (U.S. Gravity Database)

http://research.utep.edu/default.aspx?tabid=37229, North American Magnetic Database http://research.utep.edu/Default.aspx?tabid=38747, USGS South Carolina Gravity and Magnetic Data https://pubs.usgs.gov/of/2005/1022/ (Daniels and Talwani, Figure 2.3). In South Carolina, the aeromagnetic survey flight line spacing is $1.6 \mathrm{~km}$; the land gravity data has an average spatial resolution of $\sim 5 \mathrm{~km}$ (Figure 2.3). The aeromagnetic data were gridded to a $1 \mathrm{~km}$ cell size, and the land gravity data were gridded to $2 \mathrm{~km}$ cell size.
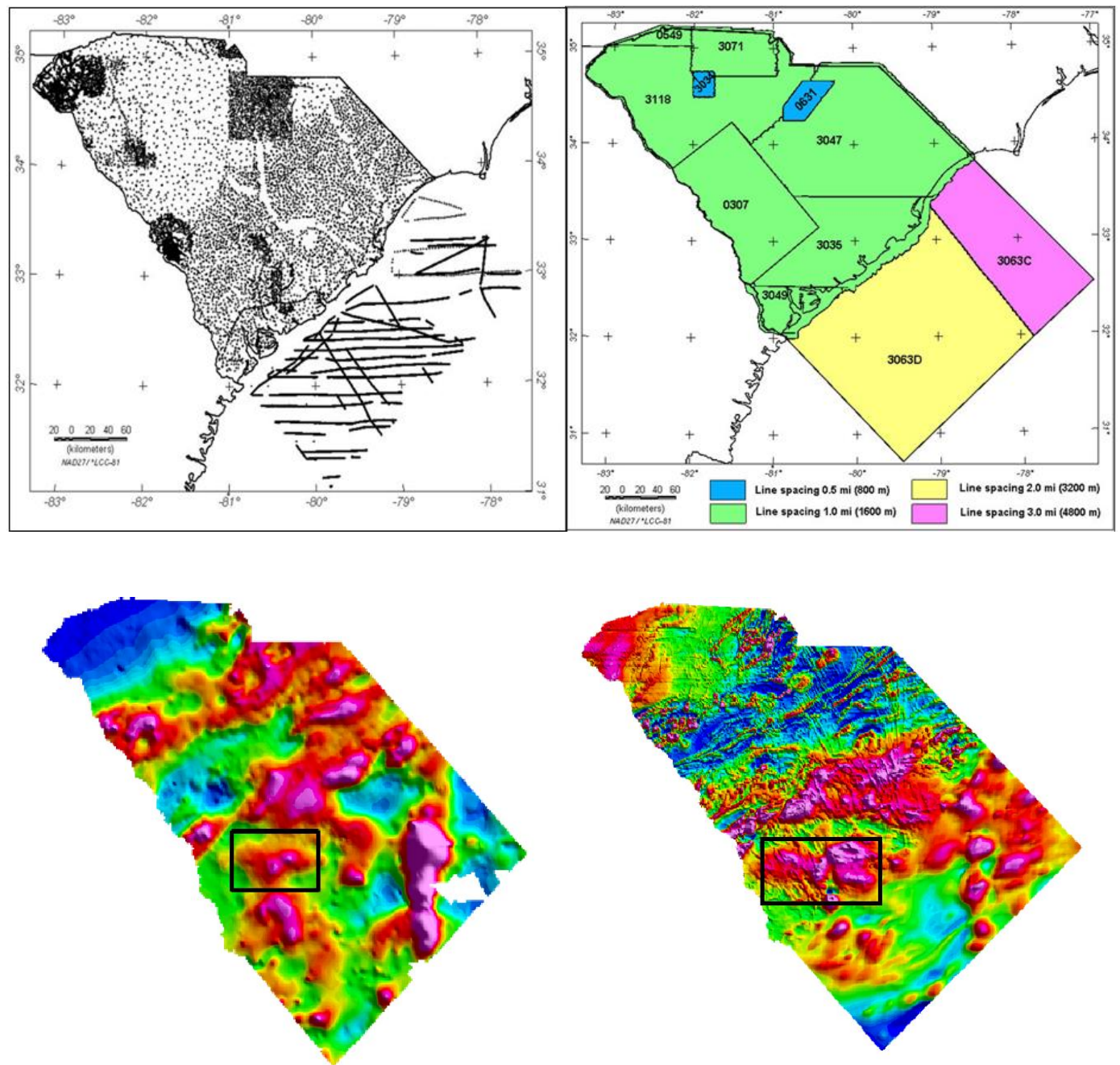

Figure 2.3 Bouguer gravity map (left) and aeromagnetic map (right) showing the study area of the Clubhouse Crossroads mafic pluton study area (black rectangle). 


\section{CHAPTER 3 \\ METHODOLOGY}

\subsection{Database}

Potential field data are from the United States Geological Survey (USGS) U.S. GravityDatabase(http://gis.utep.edu/subpages/GMData.html?option=com_content\&view $=$ article \&id=197\%3Agdrp-home\&catid=51\%3Amain-site\&Itemid=59) and the North American Magnetic Map (https://mrdata.usgs.gov/magnetic/). The aeromagnetic survey flight line spacing is $\sim 1.5 \mathrm{~km}$ and the land gravity station spacing is $\sim 5 \mathrm{~km}$. Based on the density of sample measurements, the total magnetic intensity data were gridded to a 1.0 $\mathrm{km}$ cell size, and the Bouguer land and shipborne gravity data were gridded to $2 \mathrm{~km}$ cell size.

\subsection{Rock Properties}

Rock properties, including magnetic susceptibilities, measured in centimeter gram seconds (cgs), and densities, measured in grams per cubic centimeter, are derived from laboratory measurement of rock samples from the southeastern U.S., or determined using seismic compressional-wave velocities from regional seismic surveys and Nafe-Drake equations that relate p-wave velocity to density (Ludwig et al., 1970). Because all rock properties are calibrated to samples from the region, susceptibility and density values are valid inputs to forward models. The magnetic susceptibility of diabase/gabbro is one 
exception in that magnetic susceptibility measurements have not been made from samples in the southeastern U.S., despite the fact that the rock type has been encountered in the subsurface in Georgia (Chowns and Williams, 1983) and in the Summerville oil well near the study area (Figure 2.1). The susceptibility value used in the forward model is derived from samples taken from the Newark-Gettysburg Triassic basin of Pennsylvania. This susceptibility value is valid in the context of the southeastern U.S. because the Newark-Gettysburg and South Georgia rift basins both belong to a genetically related system of rift basins that preserve Triassic strata and Upper TriassicLower Jurassic CAMP magmatism in the form of diabase sills and basalt flows (Sumner, 1977). In South Georgia, diabase from four wells intrude Newark series strata and are dated from $182 \pm$ to $209 \pm 14 \mathrm{Ma}$, which is within the range of dates reported for diabase in the Newark-Gettysburg basin (Chowns and Williams, 1983). A table of magnetic susceptibilities and densities used in potential field forward modeling appears below) (after Duff and Kellogg, 2019).

\subsection{Gravity Method}

The gravity method explores different density structures in the underground, taking advantage of the change in gravitational acceleration which is based on Newton's Law. In the method, the vertical component $(\mathrm{gz})$ of the gravitational acceleration is measured. Gravity anomalies are caused by the subsurface structures, and can be modeled in 3-D. For reliable modeling, depth information is also required. The basic gravity equation based on Newton's law is:

$$
\mathrm{F}=\mathrm{G} \frac{M m}{R^{2}}
$$


where $\mathrm{F}$ is the gravitational force between two masses, $\mathrm{M}$ and $\mathrm{m}$ are the two masses, $\mathrm{G}$ is the gravitational constant, $\mathrm{R}$ is the distance of the center of two masses (Verlinde, 2011). Under the gravitational force $F_{g}=m g, \mathrm{~g}$ is the acceleration of gravity. From this equation

$$
g=G \frac{M}{R^{2}}
$$

is the acceleration of gravity. The value of near the surface of the Earth's is $9.81 \mathrm{~m} / \mathrm{s}^{2}$ towards the center of the Earth (Parker, 2002). The unit of the acceleration of gravity is miligal (mGal) where $1 \mathrm{~m} / \mathrm{s}^{2}=100 \mathrm{Gal}=10^{4} \mathrm{mGal}$.

\subsection{Magnetic Method}

The magnetic method is one of the oldest methods used in geophysical exploration based on mathematical principles regardless of the area of the application. The purpose of the method is to analyze the changes in Earth's magnetic field. The magnetic field is more complicated and has greater variation than the gravity field. This is due to the variable direction of the magnetic field, past magnetic reversals, and the order of magnitude variations in rock magnetic susceptibility. The gravity field is always in the vertical direction and time-invariant. While the gravity method calculates the vertical component of gravity acceleration of the Earth, in the magnetic method various components of the magnetic field are measured (Telford et al., 1990).

Magnetic susceptibility is an important variant producing the induced magnetic field, as rock densities produce the gravity field. The susceptibility of rocks depends on the rock mineralogy, especially the ferrimagnetic minerals (mainly magnetite). Metamorphic and igneous rocks have much higher magnetic susceptibilities than 
sedimentary rocks (Telford et al., 1990). Table 3.1 shows the magnetic susceptibilities of various rocks and minerals.

Table 3.1 Magnetic susceptibilities of various rocks and minerals (T.M. Boyd, Colorado School of Mines, 1997).

\begin{tabular}{|c|c|c|c|}
\hline Material & $\begin{array}{c}\text { Susceptibility x 10- } \\
\text { (3) }\end{array}$ & Material & $\begin{array}{c}\text { Susceptibility x 10- } \\
\mathbf{3} \text { (SI) }\end{array}$ \\
\hline Quartz & -0.01 & Illmenite & $300-3500$ \\
\hline Rock Salt & -0.01 & Magnetite & $1200-19,200$ \\
\hline Calcite & $-0.001-0.01$ & Limestones & $0-3$ \\
\hline Sphalerite & 0.4 & Sandstones & $0-20$ \\
\hline Pyrite & $0.05-5$ & Shales & $0.01-15$ \\
\hline Rock Salt & -0.01 & Illmenite & $300-3500$ \\
\hline Hematite & $0.5-35$ & Magnetite & $1200-19,200$ \\
\hline Limestones & $0-3$ & Shales & $0.01-15$ \\
\hline Sandstones & $0-20$ & Schist & $0.3-3$ \\
\hline Gneiss & $0.1-25$ & Granite & $0-50$ \\
\hline Slate & $0-35$ & Gabbro & $1-90$ \\
\hline Basalt & $0.2-175$ & Peridotite & $90-200$ \\
\hline from T.M. Boyd of the Colorado School ofMines & &
\end{tabular}

\section{Remanent and Induced Magnetization}

No remanent magnetization was assumed for the source body in the2-D profiles (Figs. 4.9 - 4.12) and 3-D inversions. As Holbrook et al. (1994) noted, given the uncertainties in the age and duration of rifting and direction of the paleofield, estimates of the direction of remanent magnetization are difficult and involve assumptions for which there is little direct evidence. There are few direct measurements of remanent magnetization of CAMP age mafic rocks. Phillips (1983) reported paleomagnetic investigations on CAMP age basalt samples recovered from three USGS deep test holes at Clubhouse Crossroads near Charleston, S. C., where 23 flows were identified. Six of the flows had negative magnetic inclinations, which were interpreted as reversed polarity; 
one test hole contained a definite sequence of five reversed-polarity intervals separated by four normal polarity intervals. The frequent polarity reversals during the Jurassic complicate any assumption of one remanent magnetization direction. Holbrook et al. (1994) modeled the offshore Brunswick Magnetic Anomaly (BMA) signature assuming an induced anomaly from highly magnetized transitional crust with magnetic susceptibilities from 0.026 to $0.035 \mathrm{cgs}$. Austin et al. (1990) modeled the BMA source as a strong, remanently magnetized mafic body (0.045 to $0.067 \mathrm{cgs})$, assuming an Early Jurassic paleofield: declination $=-2.2^{\circ}$, inclination $=46.0^{\circ}$. Davis, et al., (2018) investigated emplacement rates for packages of basalt flows (seaward dipping seismic reflectors or SDRs) that form part of the source of the East Coast Magnetic Anomaly (ECMA), offshore North Carolina. Using the measurements of Philips (1983), they found that the combination of varying-polarity basalt layers causes the remanent anomalies of the layers to cancel out, significantly limiting the amplitude that the integrated magnetic anomaly can produce. Therefore, at reasonable rates of continental extension $(<20 \mathrm{~mm}$ yr-1) and magnetic chron duration (0.5 Ma), modeling results preclude the development of large, exclusively positive, high amplitude magnetic anomalies from remanent magnetization. Instead, Davis, et al. (2018) conclude that the ECMA is best explained as an induced magnetic anomaly from SDRs with a magnetic susceptibility of $0.05 \mathrm{cgs}$. Both induced and remanent solutions can produce the BMA offshore, and both models require a highly magnetized mafic source (Duff and Kellogg, 2019). Given the similarities in the expected magnetic anomalies produced and the uncertainties regarding the polarity of remanent magnetization, I assumed induced magnetization for our onshore source. 


\subsection{Interpretation Methods}

The potential field data are interpreted in order to map the subsurface structures such as faults, dikes and contacts. The interpretation has been done by applying the following techniques: Tilt Derivative, Reduced to Pole, Analytical Signal, and 2-D modelling in Geosoft Oasis Montaj (version 9.2) software.

\section{Tilt Derivative}

Tilt derivative method provides a simple and fast way to estimate the dept to the magnetic basement for large areas, and to enhance the shallow features. Tilt derivative is the first order of the reduced to pole (RTP) (Fairhead et al 2010). Verduzco et al. 2004 defined the generalized local phase of the Tilt angle as:

$$
\begin{gathered}
\theta=\tan ^{-1}\left(\frac{\frac{\partial t}{\partial z}}{\frac{\partial t}{\partial x}}\right) \\
\tan \theta=\left(\frac{\frac{\partial t}{\partial z}}{\frac{\partial t}{\partial x}}\right)
\end{gathered}
$$

Where Vertical derivative $V D R=\sqrt{\left(\frac{\partial t}{d z}\right)^{2}}$, and Total horizontal derivative $T H D R=\sqrt{\left(\frac{\partial t}{d x}\right)^{2}+\left(\frac{d t}{d y}\right)^{2}} \cdot$ Also, TDR are defined as:

$T D R=\tan ^{-1}\left(\frac{\frac{\partial t}{\partial z}}{\frac{\partial t}{\partial x}}\right)$ for profile in $\mathrm{x}$ direction.

$T D R=\tan ^{-1}\left(\frac{V D R}{T H D R}\right)$ Grid $(\mathrm{x}, \mathrm{y})($ Mousa and Al-rahim,2016).

\section{Analytical signal}

Analytical signal (AS) is one of the common methods to interpret potential field data, also known as the total gradient technique. The technique is used to estimate the 
depth and the edge of the structure, causing the anomaly. One significant advantage of AS is its independence from the direction of magnetization of the source. The technique is applied by peaking over the magnetic structure with local maxima over its boundaries or contacts (Mousa and Al-rahim, 2016).

$$
A S=\sqrt{\left(\frac{d t}{d x}\right)^{2}+\left(\frac{d t}{d y}\right)^{2}+\left(\frac{d t}{d z}\right)^{2}}
$$

where $\sqrt{\left(\frac{d t}{d x}\right)^{2}+\left(\frac{d t}{d y}\right)^{2}}$ is the horizontal derivative and $\sqrt{\left(\frac{d t}{d z}\right)^{2}}$ is the vertical

derivative. Thus, AS method depends on the first order derivatives of the horizontal and

the vertical derivatives in the $\mathrm{x}, \mathrm{y}$, and $\mathrm{z}$ directions (Salem et al 2005). The resolution the of analytic signal is less than the horizontal derivative (Mousa and Al-rahim 2016)

\section{Reduced to Pole}

Reduced to pole is a technique which is being applied in the frequency domain in order to convert the magnetic anomaly to a symmetrical pattern that can also be observed from vertical magnetization (Ansari and Alamdar, 2009).

The magnetic anomaly shape relies on the susceptibility, shape of the body, the direction of its magnetization and direction of the regional field. If the magnetization regional field is vertical, the RTP technique transforms an anomaly into the anomaly that is detected (Alarifi, 2017). This technique is based on removing asymmetries of anomalies caused by nonvertical magnetization (Dobrin and Savit, 1988). However, removing the effect of the magnetic latitude from the anomalies reduces the total field to magnetic pole (Alarifi, 2017). Macleod et al (1993) has indicated that RTP can be calculated in the wavenumber domain using the following equation, 
$\mathrm{L}(\theta)=\frac{I}{(\sin \cdot I a=i \cos \cdot \cos (D-\theta))^{2}}$

where $\theta$ is the wavenumber direction, I is the magnetic inclination, $\mathrm{D}$ is the magnetic declination and $I a$ is the inclination for amplitude correction.

\section{Euler Deconvolution Inverse Modelling}

Inverse modeling of total field magnetic data was performed by 3D located Euler deconvolution. Euler deconvolution estimates the depth and location of a magnetic source by examining the rate of change of the magnetic field as a function of distance (Thompson, 1982; Reid et al., 1990). This technique can be applied to profile or grid data to solve for Euler's Homogeneity Equation:

$$
\left(x-x_{0}\right) d F / d x+\left(y-y_{0}\right) d F / d y+\left(z-z_{0}\right) d F / d z=N(B-F)
$$

where $\mathrm{x}_{0}, \mathrm{y}_{0}, \mathrm{z}_{0}$ is the source location whose magnetic field is $\mathrm{F}$, measured at point $\mathrm{x}, \mathrm{y}, \mathrm{z}$. $\mathrm{B}$ is the regional value of the Total Field. $\mathrm{N}$ is the Euler's structural index (SI), which characterizes the source's geometry. The SI can be varied from zero to three: 0 (contact of infinite depth), 1 (dike), 2 (pipe), and 3 (sphere). The Euler method also yields estimates of the standard deviation of $z_{0}$. This quantity $\sigma_{0}$ is treated as an "error bar" on the depth estimate and forms the basis for an algorithm that determines whether or not a depth estimate is to be retained. This feature permits an uncertainty level in the depth estimate to be set such that all solutions falling below that threshold are discarded (Duff and Kellogg, 2019).

Inverse modeling by 3D located Euler deconvolution involves a reduction to magnetic pole transform, and the calculation of an analytic signal grid. The reduction to magnetic pole transform converts magnetic data recorded in the inclined Earth's 
magnetic field to what they would look like at the magnetic pole, where the magnetic field is vertical. The transform locates anomalies above causative bodies, assuming that remanent magnetism is small relative to induced magnetism. The amplitude of the analytic signal is the square root of the sum of the squares of the derivatives in the $\mathrm{x}, \mathrm{y}$, and $\mathrm{z}$ directions (Duff and Kellogg, 2019):

$$
A(x, y)=\left(d x^{2}+d y^{2}+d z^{2}\right)^{1 / 2}
$$

The analytic signal is useful in locating magnetic sources, particularly where remanent magnetization or low magnetic latitude complicates interpretation, because the amplitude of the analytic signal of the total magnetic field produces a peak over magnetic contacts regardless of the direction of magnetization (MacLeod, et al., 1993). The peak values from analytic signal grid are used to guide the Euler algorithm in order to reduce the number of Euler solutions and the associated uncertainty (Thompson, 1982). Euler results were obtained using a structural index of two and a depth uncertainty of ten percent.

\section{Forward Modelling}

Simultaneous forward modeling of gravity and magnetic data was performed using an interactive, iterative technique within Geosoft GM-SYS software, which incorporates the methodology of Talwani et al. (1959) and Talwani and Heirtzler (1964) for computing the gravitational and magnetic response from a specified horizontal prism with a simple cross-sectional polygon geometry (in the plane of the model profile) and assigned density and magnetic susceptibility. Because of the elliptical shape of the magnetic source, a $2.5 \mathrm{D}$ forward model algorithm was used to calculate the resulting gravitational and magnetic fields. The $2.5 \mathrm{D}$ method allows the user to place finite limits 
on the horizontal prisms that would normally extend to infinity in 2-D models. Polygon geometries, including the base of coastal plain sediments, base of Triassic basin fill, and depth to Moho, were constrained by three boreholes to the base of the coastal plain sediments, the Seisdata-4 seismic reflection data, and a seismic refraction velocity model (Leutgart et al., 1994). The geometry of these boundaries are important because they represent the strongest density contrasts along the model profile. With these preliminary geometries set, the polygons were assigned representative density and magnetic susceptibility values. Then polygon geometry, as well as assigned density and magnetic susceptibility values, for the intrusion that is the source of the Clubhouse Crossroads mafic pluton anomaly were varied to produce a consistent model solution, for which calculated anomaly best fit the observed anomaly.

\subsection{3-D Inversion Methods}

\section{3-D Inverse Modelling}

GM-SYS 3D utilizes a combination of Fast-Fourier Transform (FFT) and space-domain algorithms to calculate the total response of your model. Fast-Fourier Transform (FFT) and space-domain algorithms were used to calculate the total model response. Forward calculations were based on frequency-domain techniques by Parker (1972) and Blakely (1995). The continuous 3-D Fourier transform is defined according to the following convention

$$
f_{3 \mathrm{D}}[y(x)] \equiv \hat{y}(k) \equiv \int_{R^{3}}^{\infty} y(x) e^{-i k \cdot x} d x
$$

Where (1) $f_{3 D}$ is the Fourier operator $\mathrm{X}=(\mathrm{x}, \mathrm{y}, \mathrm{z})$ is the spatial position $\mathrm{K}$ is the 3 -D wave vector where $\mathrm{k} \equiv\left(k_{x}, k_{y}, k_{z}\right)$ and $R^{3}$ is the infinite 3 -D domain of real numbers where the 
function $\mathrm{y}(\mathrm{x})$ is defined. $\mathrm{y}(\mathrm{x})$ is characterized by good convergence properties and satisfying the condition

$$
\int_{R^{3}}|y(x)| d x<+\infty
$$

which ensures the Fourier transform equation (Tontini et al 2009).

\section{Derivation of Parker's Gravity Equations}

Tontini et al. (2009) demonstrated the generality and validity of the equations showing how can be recovered the particular well-known case of Parker 1972. If a density layer contained within two undulating surfaces $z_{1}(x, y)$ and $z_{2}(x, y)$, and thus the density is given by

$$
\rho(x)=\rho_{h}(x, y)
$$

where $z_{1}(x, y)<z<z_{2}(x, y)$, and vanishes outside. The gravity equation

$$
f_{3 \mathrm{D}}\left[\Delta g_{z}\right]=\frac{i 4 \pi G k_{z}}{k_{x}^{2}+k_{y}^{2}+k_{z}^{2}} \int_{-\infty}^{+\infty} \int_{-\infty}^{+\infty} \rho_{h}(x, y) e^{-i\left(k_{x} x+k_{y} y\right)} d x d y \int_{z_{1}(x, y)}^{z_{2}(x, y)} e^{-i k_{z} z} \mathrm{dz}
$$

The integral along $\mathrm{z}$ is easily calculated.

$$
f_{3 \mathrm{D}}\left[\Delta g_{z}\right]=\frac{i 4 \pi G k_{z}}{k_{x}^{2}+k_{y}^{2}+k_{z}^{2}} \int_{-\infty}^{+\infty} \int_{-\infty}^{+\infty} d x d y \rho_{h}(x, y) e^{-i\left(k_{x} x+k_{y} y\right)}\left[\frac{i}{k_{z}} e^{-i k_{z} z_{2}(x, y)}-e^{-i k_{z} z_{1}(x, y)}\right]
$$

The final equation

$f_{3 \mathrm{D}}\left[\Delta g_{z}\right]=\frac{-4 \pi G}{k_{x}^{2}+k_{y}^{2}+k_{z}^{2}} \int_{-\infty}^{+\infty} \int_{-\infty}^{+\infty} d x d y\left(e^{-i k_{z} z_{2}(x, y)}-e^{-i k_{z} z_{1}(x, y)} \rho_{h}(x, y) e^{-i\left(k_{x} x+k_{y} y\right)}\right.$

\section{3-D Matlab Gravity Depth Inversion}

In this study, 3-D gravity depth inversion was also accomplished using Matlab software. This technique is employed to locate the edges of the features. The math calculations are based on Fast Fourier Transformation (FFT). The technique is based on 
the tilt angle of the first vertical gradient of gravity anomaly (Oruc, 2011). The technique was first proposed by Miller and Singh (2003), and developed by Verduzco et al. (2004) in order to be used for gridded data, and suggested to be used with the total horizontal derivative of the tilt angle as an edge detector (Oruc, 2011). The tilt angle is described with the equation

$$
T D R=\tan ^{-1}\left(\frac{\partial f / \partial z}{\sqrt{(\partial f / \partial x)^{2}+(\partial f / \partial y)^{2}}}\right)
$$

where $f$ is the magnetic or gravity field and $\partial f / \partial x, \partial f / \partial y$, and $\partial f / \partial z$ are the first derivative in $\mathrm{x}, \mathrm{y}$, and, $\mathrm{z}$ directions. The tilt amplitudes range between $-\pi / 2$ and $+\pi / 2$ which corresponds to a wide dynamic range of amplitudes for sources at different depths (Oruc, 2011). Verduzco et al. (2004) stated that the angle is also employed as an automatic- gain-control-filter in order to equalize the results from weak and strong potential field anomalies. If the tilt angle technique is applied to the first vertical gradient $\left(\partial^{2} g_{z} / \partial z\right)$ of the gravity field $\left(g_{z}=f\right)$, it provides new angle equation (Oruc, 2011)

$$
\emptyset=\tan ^{-1}\left(\frac{\partial^{2} g_{z}}{\sqrt{\left(\frac{\partial^{2} g_{z}}{\partial_{x} \partial_{z}}\right)^{2}+\left(\frac{\partial^{2} g_{z}}{\partial_{y} \partial_{z}}\right)^{2}}}\right)
$$

Fast Fourier Transform (FFT) technique calculates the vertical gradient of gravity data. Also, it calculates the vertical derivative of $g_{z}$ which is necessary for the calculation of tilt angle (Oruc, 2011). The Gravity Fourier equation is

$$
\Delta g z\left(x_{0}\right)=G \int_{R^{3}} \frac{\rho(x)\left(z-z_{0}\right)}{\left|x-x_{0}\right|^{3}} d x
$$


where $\mathrm{G}=6.67 \times 10^{-11} \mathrm{~N} . \mathrm{m}^{2} / \mathrm{kg}^{2}$ is the gravitational constant, $\rho$ is the density

distiribution in $\mathrm{kg} \cdot \mathrm{m}^{-3}, \mathrm{x}=(\mathrm{x}, \mathrm{y} . \mathrm{z})$ is the vector position of source volume,

$x_{0}=\left(x_{0}, y_{0}, z_{0}\right)$ is the vector of the measurement.

\section{VOXI Earth Modelling}

3-D inversion of the gravity data was also accomplished by using the VOXI earth modelling tool in Geosoft Oasis Montaj. VOXI earth modelling is based on the algorithm of Li and Oldenburg (1998) with the density values from 2-D forward modelling results (Table 4.1). The tool minimizes the data misfit, and the model is updated through inversion. The inversion uses several iterations which are run until the difference between the gravity average of the inverted density model and the predicted model is reduced sufficiently (Kanthiya et al., 2008). The result of the final inversion model is a geometric model of the subsurface layers. The objective function

$$
\varphi T=\varphi d+\lambda \varphi m
$$

where $\lambda$ regularization parameter that is adjusted by the inversion algorithm in successive steps. Each $\lambda$ represents the iteration in the inversion. The final model is the one that minimizes the objective function with the condition that is specified. When the misfit is close to 1 , the inversion has successfully minimized the objective function based on the criteria.

Li and Oldenburg (1998) have proposed a gravity inversion using a vertical component of gravity field. The direct gravity inversion using vertical component of gravity field at ith observation location $r_{i}$

$$
F_{z}\left(r_{i}\right)=\gamma \int_{V} \rho(r) \frac{z-z_{i}}{\left|r-r_{i}\right|^{3}} d v
$$


Where $\rho(r)$ is the mass distribution caused anomaly, and $\gamma$ is Newton's gravitational constant. The data misfit is given by

$$
\varphi_{d}=\left\|W_{d}\left(d-d^{o b s}\right)\right\|_{2}^{2}
$$

where $d^{o b s}=\left(F_{z 1}, \ldots, F_{z N}\right)^{T}$ is the data vector, $d$ is the predicted data, $W_{d}=$ $\operatorname{diag}\left\{1 / \sigma_{1}, \ldots, 1 / \sigma_{N}\right\}$ and $\sigma_{i}$ is the error standard deviation and also is associated with the ith datum. The highest confidence model is the one that makes $\emptyset_{d}$ very small. The purpose is here to reduce the misfit to the desired value.

The objective function of the form,

$$
\begin{gathered}
\varphi_{d}(\rho)=a_{s} \int_{V} w_{s}\left\{w(z)\left[\rho(r)-\rho_{0}\right]\right\}^{2} d v \\
+a_{x} \int_{V} w_{x}\left\{\frac{\partial w(z)\left[\rho(r)-\rho_{0}\right]}{\partial x}\right\}^{2} d v \\
+a_{y} \int_{V} w_{y}\left\{\frac{\partial w(z)\left[\rho(r)-\rho_{0}\right]}{\partial y}\right\}^{2} d v \\
+a_{z} \int_{V} w_{z}\left\{\frac{\partial w(z)\left[\rho(r)-\rho_{0}\right]}{\partial z}\right\}^{2} d v
\end{gathered}
$$

where $w_{s}, w_{x}, w_{y}$, and $w_{z}$ dependent weighting functions. $w_{z}$ is a depth weighting function. $a_{s}, a_{x}, a_{y}$, and $a_{z}$ are coefficients that affect the significance of different components in the objective function (Li and Oldenburg, 1998). 


\section{CHAPTER 4}

\section{RESULTS AND CONCLUSIONS}

\subsection{Magnetic Results}

\section{Total Magnetic Intensity (TMI)}

Total magnetic intensity anomaly ranges between 414.4 and $-159.1 \mathrm{nT}$ in the study area. The maximum values indicate CAMP intrusive plutons in light pink color. Blue and green colors are associated with low anomaly values (Map 4.1).

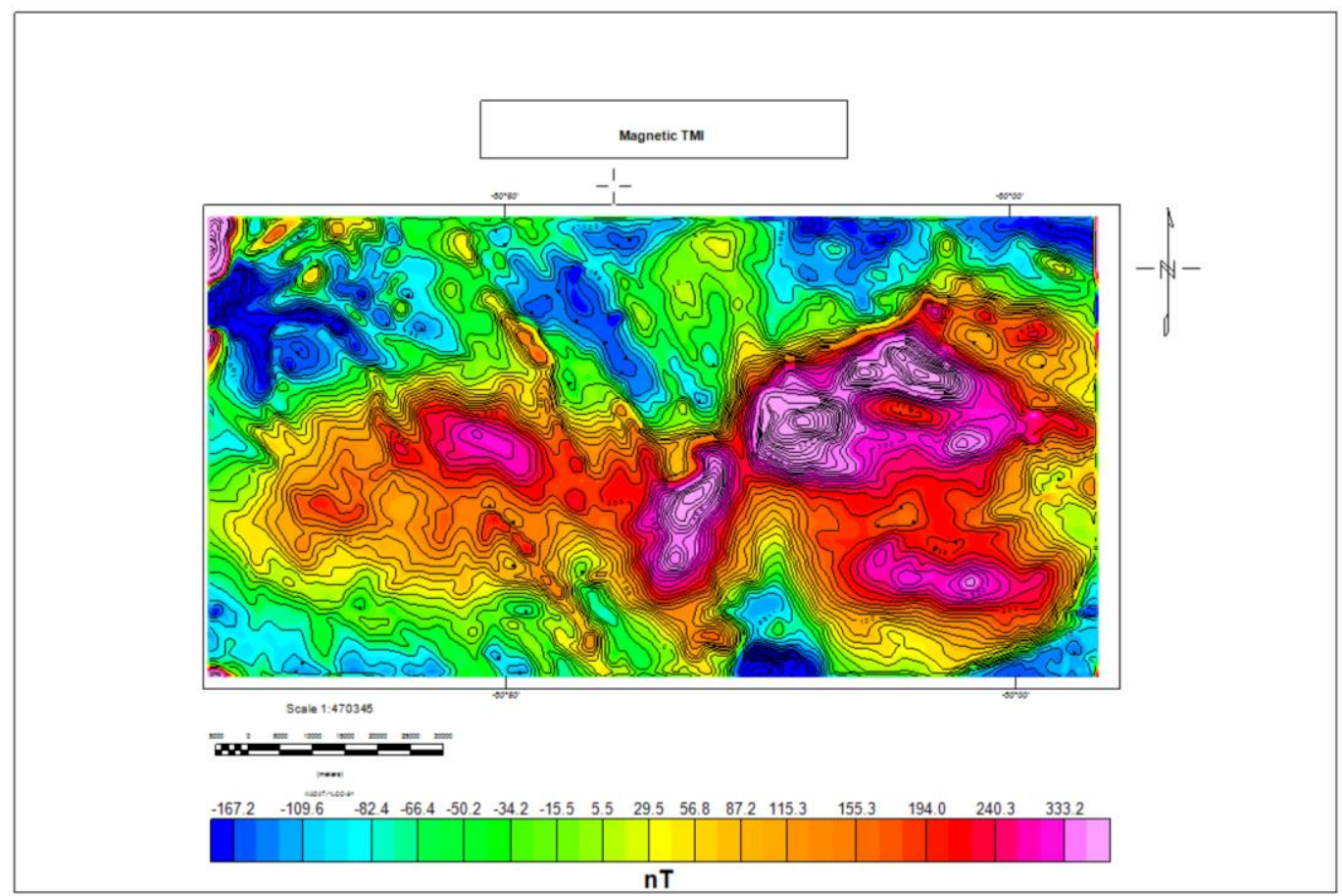

Figure 4.1 Total Magnetic Intensity of study area.

\section{Reduced to Pole (RTP)}

Reduced to pole (RTP) filter is used to migrate the observed field 
from abservation inclination and declination to what the field which is at the magnetic pole. RTP filter locates anomaly directly above the source (Figure 4.2).

The method is based on inclination and declination angle removal. There are small differences between TMI and RTP. Map (Figure 4.2) highlights the high values over the CAMP mafics in the range between $\sim 268-\sim 480 \mathrm{nT}$.

The analysis of the total magnetic intensity when using the reduced to pole method produced a reduction in the effect of magnetic variations caused by the dipole magnetic field. The observed field from observation inclination and declination migrates to what the field would look like at the magnetic pole. This aids in the interpretation, since any asymmetry in the reduced to pole field can be attributed to source geometry and/or magnetic properties (Geosoft). The anomalies in the RTP magnetic map are located directly above the source. This method uses inclination and declination values of 630 and -7.200 .

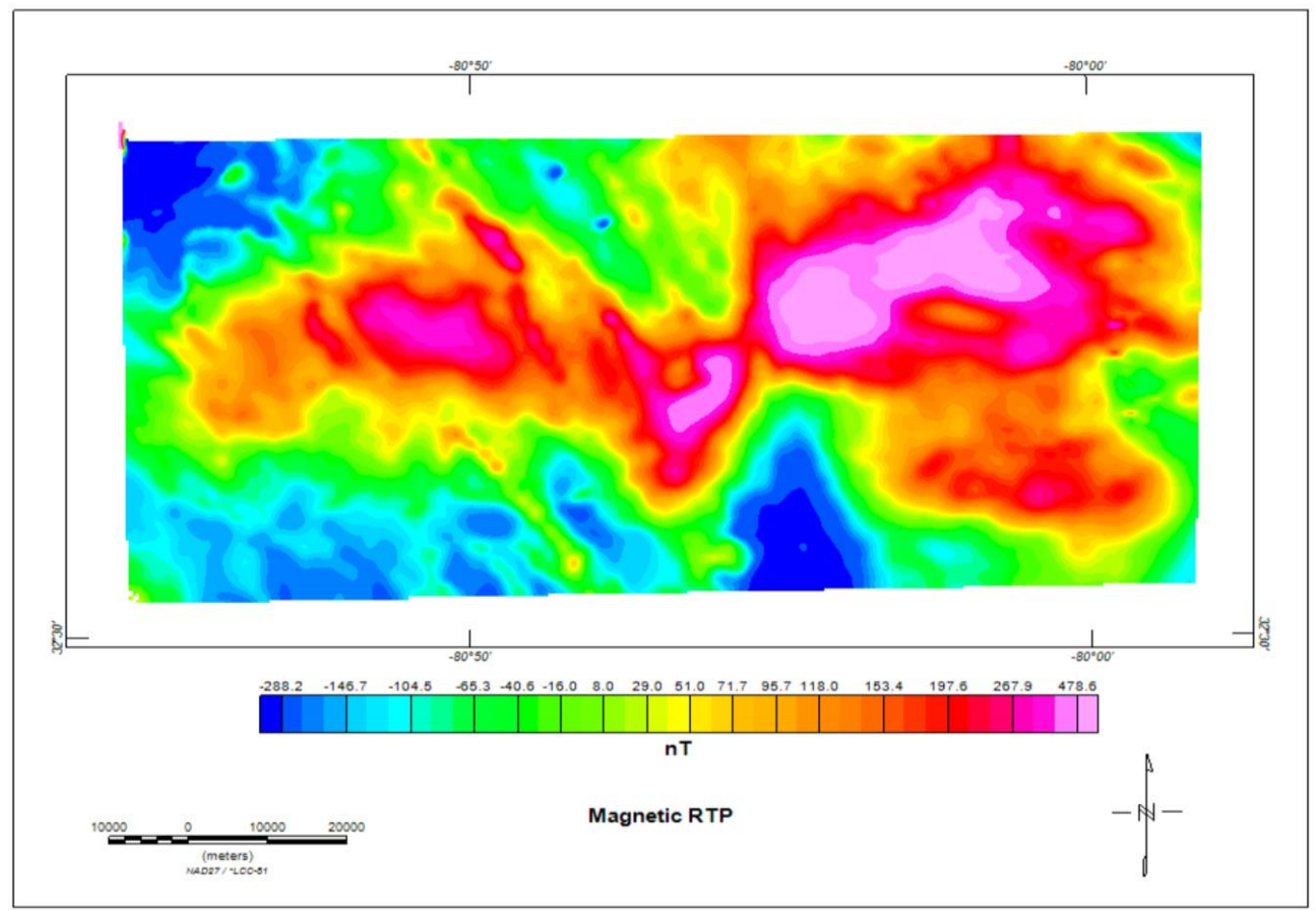

Figure 4.2 Reduced to Pole Map 


\section{Analytical Signal Method (AS)}

The analytic signal (AS) method was succesfully applied to the magnetic anomaly data. The analytic signal is peaked over the location of the causative anomaly bodies. The AS calculations are independent of the earth magnetic field direction.

Therefore, the anomalies are shifted to the top of the source bodies. Figure 4.3 shows the CAMP bodies. The anomalies shown in blue and green colors show the values of low magnetic anomalies. Additionally, the high AS anomalies shown in pink and red colors of CAMP mafics were highlighted after applying the reduced to pole filter (Figure 4.3).

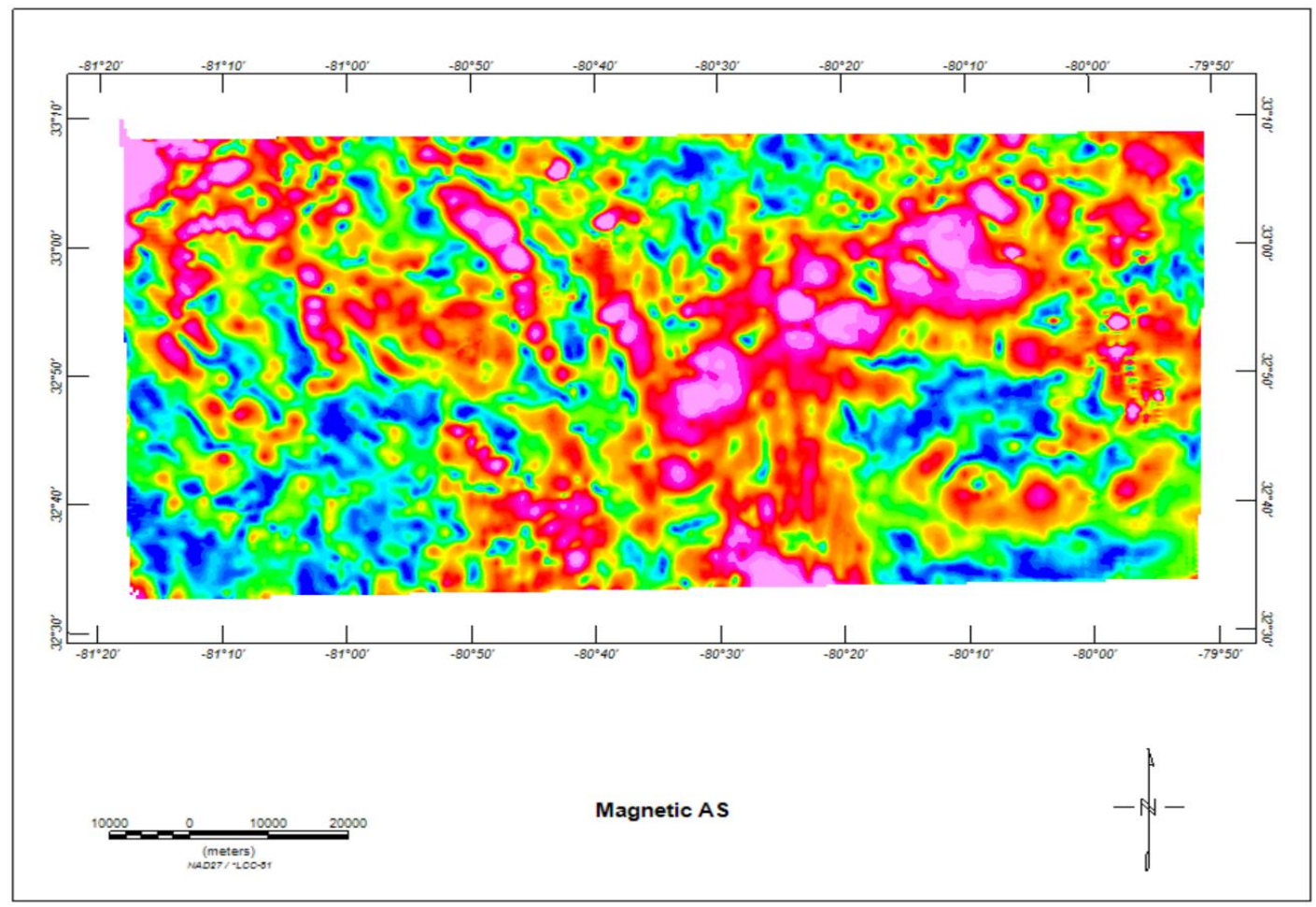

Figure 4.3 Analytic Signal of the Total Magnetic Intensity Map

\section{Tilt Derivative Method (TDR)}

The tilt derivate method was used to enhance and sharpen the magnetic anomalies of the source body. Northwest trending Jurassic (CAMP) mafic dikes can be easily identified on the tilt derivative map clearly (Figure 4.4). 


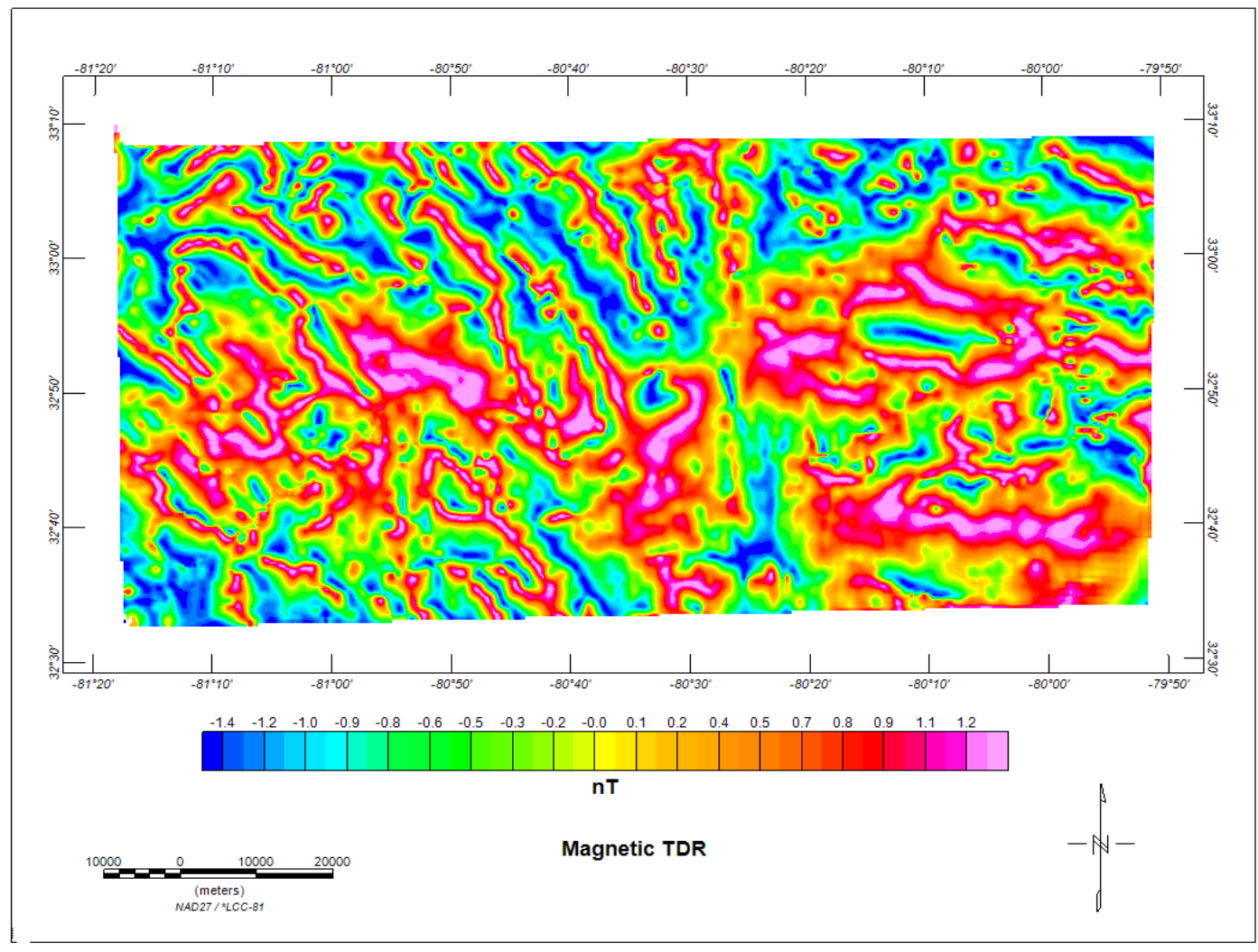

Figure 4.4 Tilt derivative of the reduced to the pole magnetic anomalies.

\subsection{2-D Forward Modeling of Potential Field Data}

I began with 2-D forward modeling because profile geometry can be constrained by well, seismic, gravity, and magnetic data. The forward modeling of potential field data was performed using Geosoft GM-SYS software with an interactive method based on the methodology of Talwani et al (1959) and Talwani and Heirtzler (1964) for computing the gravitational and magnetic response from a specified horizontal prism with a simple cross-section polygon geometry based on density and susceptibility (Duff and Kellogg, 2019). There are 4 model profiles (Figure 4.5) constructed over the CAMP Clubhouse Crossroads mafic pluton based on well, seismic, gravity, and magnetic data. Profile 1 was constructed by Duff (2015) based in part on the SEISDATA 4 seismic reflection profile and was used as a reference profile for the others (Figure 4.5). 


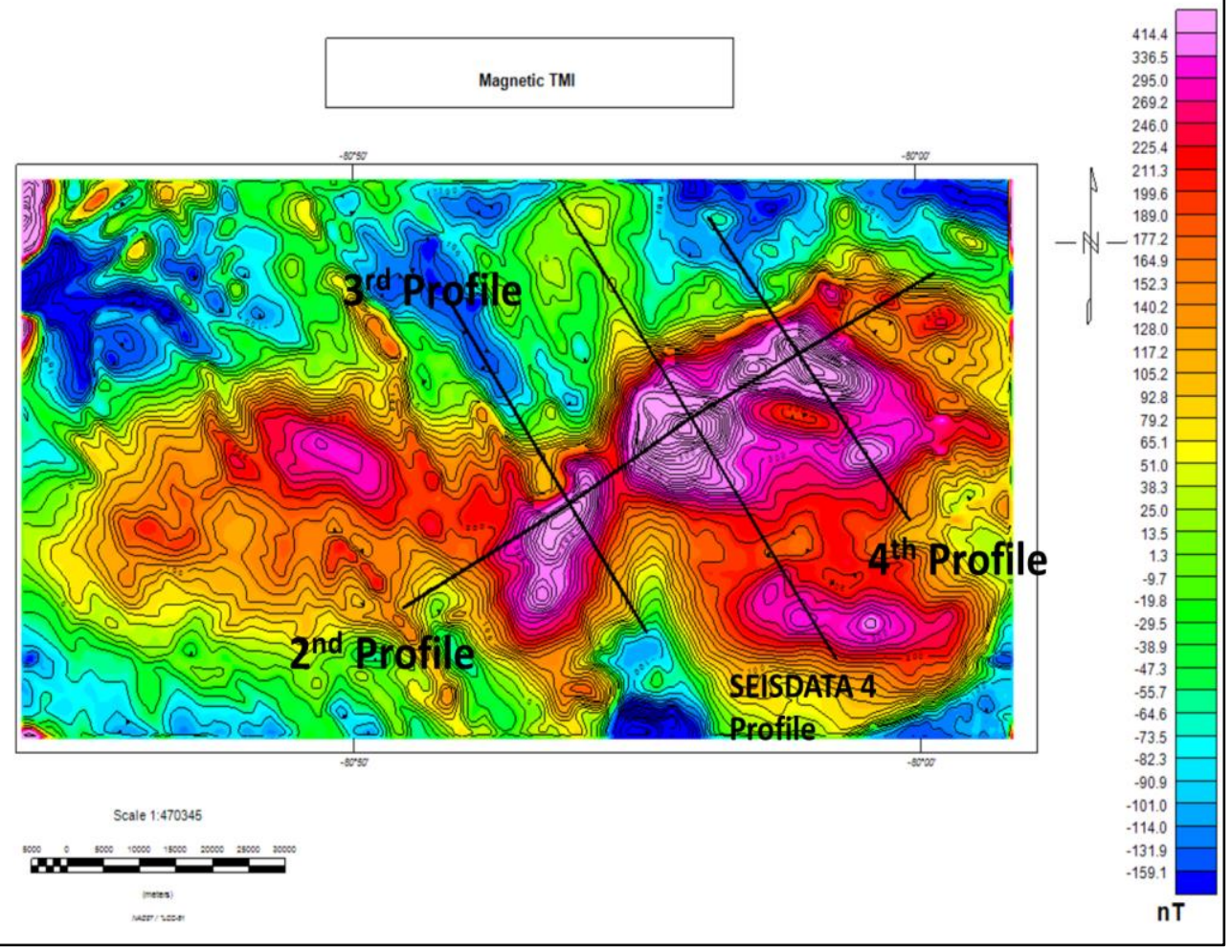

Figure 4.5 Forward model profile locations shown on the Total Magnetic Intensity Map.

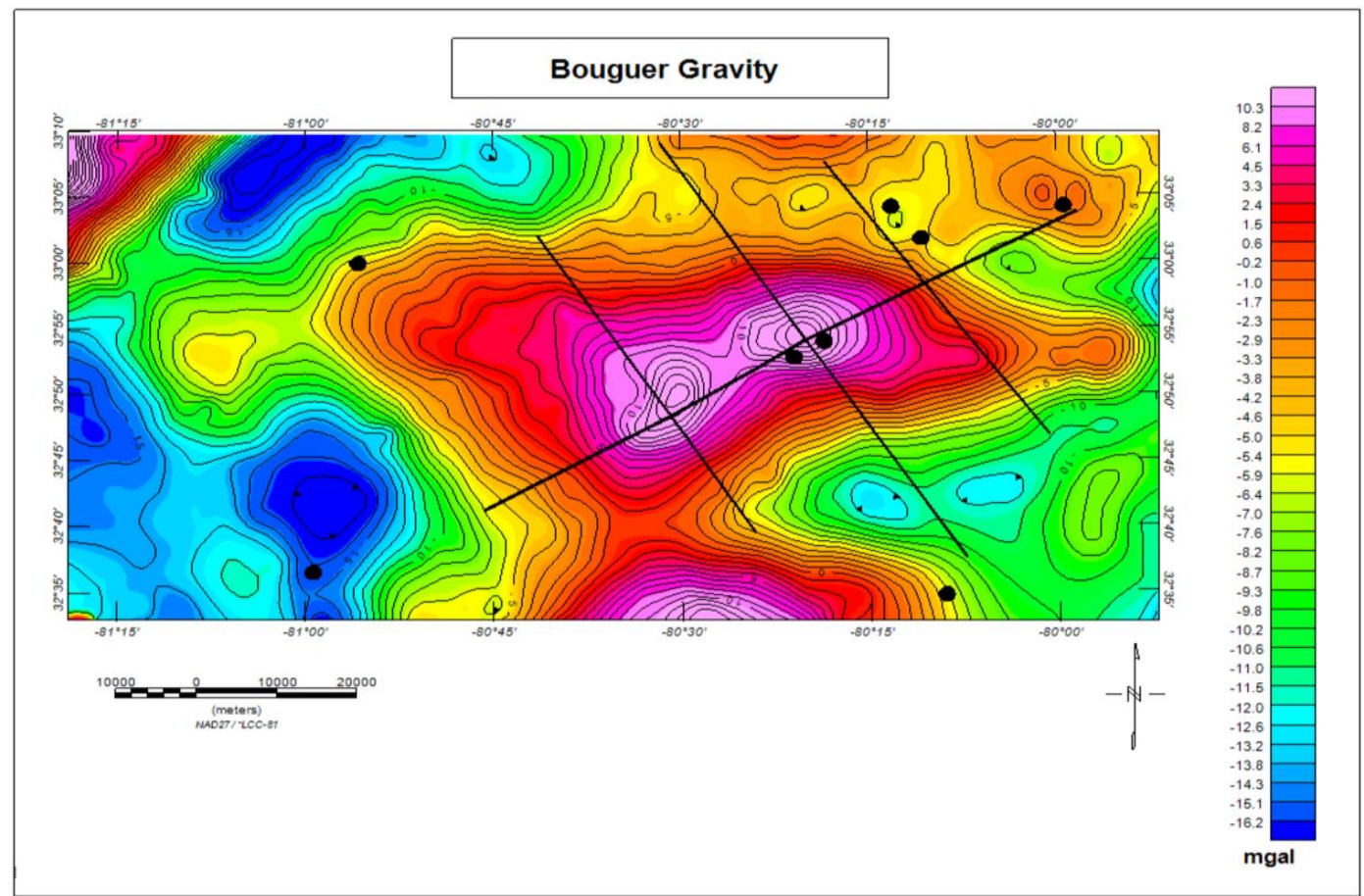

Figure 4.6 Forward model profiles located on the Gravity Map. Available wells in the study area are shown as black dots. 
Table 4.1 Densities Used in Forward Modeling (Duff and Kellogg, 2019)

\begin{tabular}{|c|c|c|}
\hline Unit & Density $\left(\mathrm{g} / \mathrm{cm}^{3}\right)$ & Reference \\
\hline Allochthonous Crust (per- & 2.75 & Holbrook, et al. (1994) \\
\hline \multirow[t]{2}{*}{ Gondwanan/Gondwanan) } & & Cumbest, et al. (1992) \\
\hline & & Luetgert, et al. (1994) \\
\hline \multirow[t]{3}{*}{ Mafic Intrusions } & 3.0 & Duff, et al. (2017) \\
\hline & & Cumbest, et al. (1992) \\
\hline & & Beck (1965) \\
\hline \multirow[t]{2}{*}{ Coastal Plain Sediments } & 2.0 & Luetgert, et al. (1994) \\
\hline & & Cumbest, et al. (1992) \\
\hline \multirow[t]{2}{*}{ Triassic Sediments } & 2.45 & Luetgert, et al. (1994) \\
\hline & & Cumbest, et al. (1992) \\
\hline \multirow[t]{2}{*}{ Basement } & $2.94-3.04$ & Luetgert, et al. (1994) \\
\hline & & Christensen, et al. (1995) \\
\hline \multirow[t]{2}{*}{ Mantle } & 3.42 & Luetgert, et al. (1992) \\
\hline & & Christensen (1989) \\
\hline Basalt & $2.73-3.3$ & Sharma (1997) \\
\hline Gabbro & $2.85-3.12$ & Sharma (1997) \\
\hline Diabase & $2.8-3.1$ & Sharma (1997) \\
\hline
\end{tabular}


Table 4.2 Densities Used for Basalt, Diabase, and Gabbro

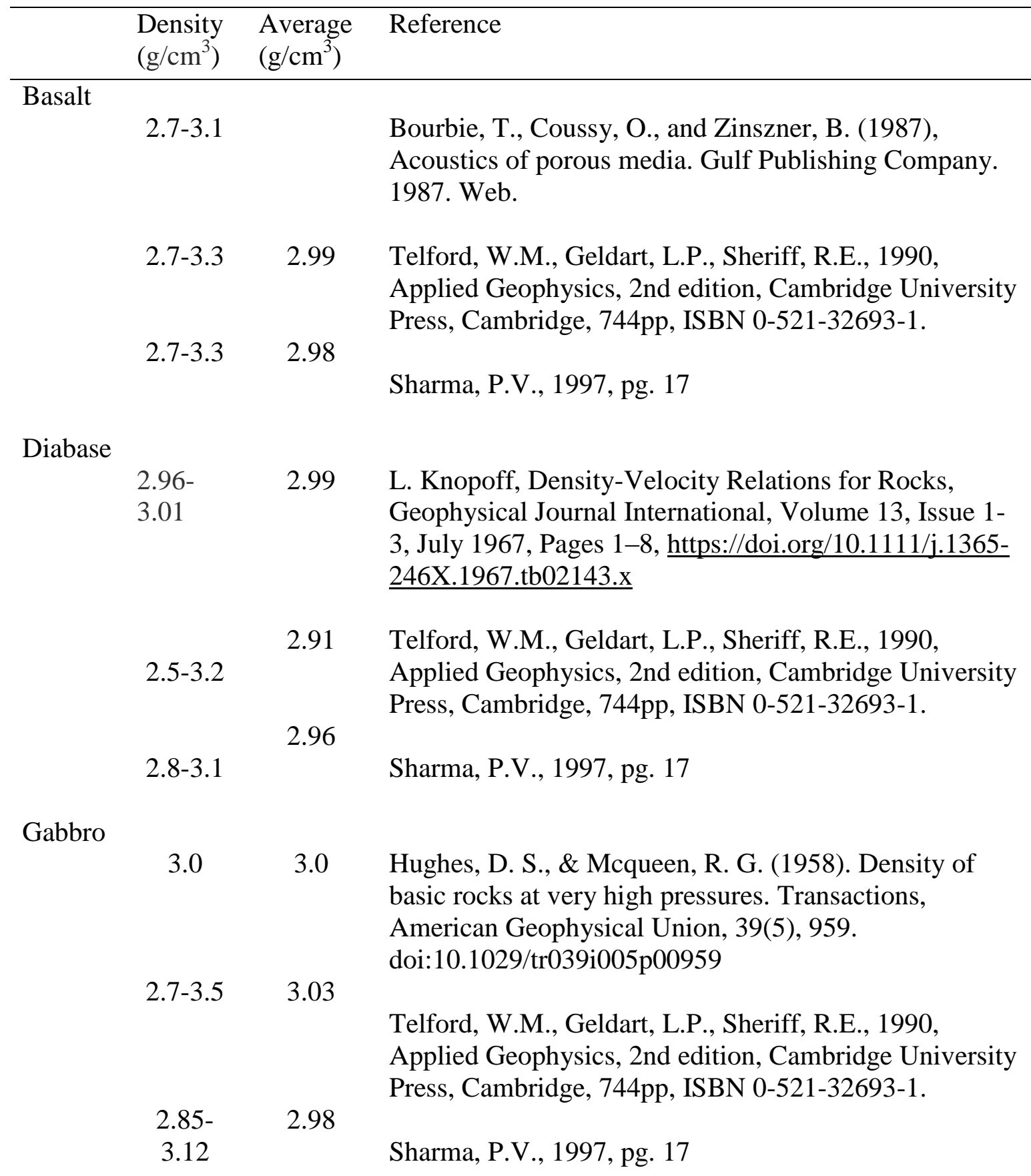

It is clear that the densities of some sedimentary lithologies increase significantly with depth as compaction reduces pore space. 
Table 4.3 Magnetic Susceptibilities Used in Forward Modelling

\begin{tabular}{ccc}
\hline Unit & Susceptibility (cgs) & Reference \\
\hline Allochthonous Crust (per- & 0 & Sumner (1997) \\
Gondwanan/Gondwanan) & 0.012 & Sumner (1977) \\
Mafic Intrusions & & Beck (1965) \\
Coastal Plain Sediments & 0 & Cumbest et al. (1992)
\end{tabular}

The 2-D model polygon geometries include the base of the coastal plain sediments, Triassic basin horizons, the mafic pluton, and crustal layers. Table 4.1 and Table 4.2 show the density and the susceptibility values used for profile polygons.

No remanent magnetization was assumed for the CAMP mafics in any of the profiles. Hollbrook et al (1994) indicated that it is difficult to estimate the remanent magnetization with little direct evidence given uncertainties in the age, duration, and direction of the paleofield (Duff and Kellogg, 2019).

\section{SEISDATA 4 Profile 1}

The first profile follows a segment of the SEISDATA 4 seismic reflection line. The calculated gravity and magnetic fields for the model fit the observed fields. The body averages $\sim 1.5 \mathrm{~km}$ thick and is located at $1-3 \mathrm{~km}$ depth. The assumed density for Upper CAMP is 2.88 and the susceptibility is 0.015 . The assumed density for Lower CAMP is 3.2, and the susceptibility is 0.012 (Figure 4.9 ). The body extends $\sim 35 \mathrm{~km}$ along the profile. 


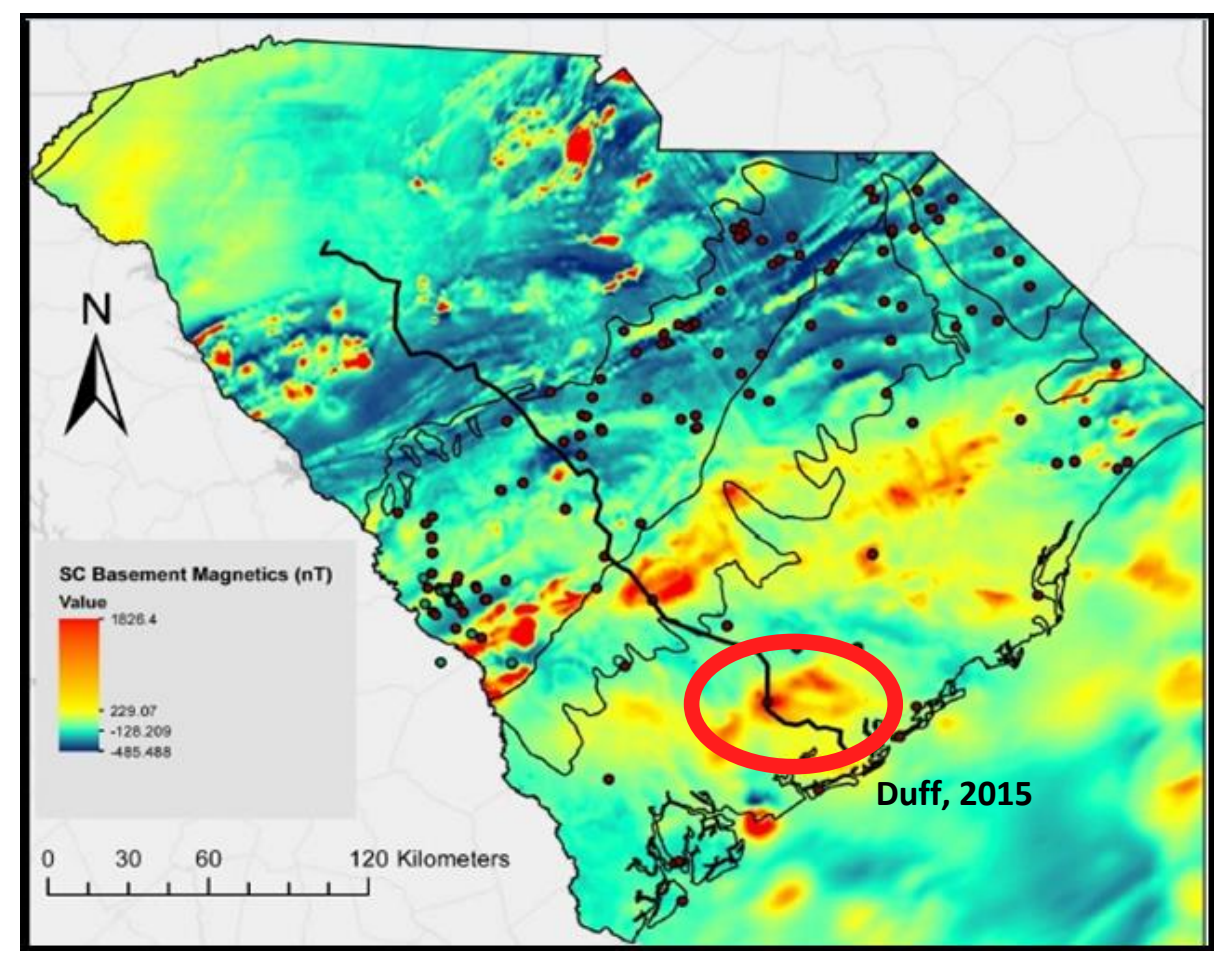

Figure 4.7 Magnetic Map of South Carolina showing the Clubhouse Crossroads mafics in red oval.

The figure below is a part of the SEISDATA 4 Seismic reflection profile.

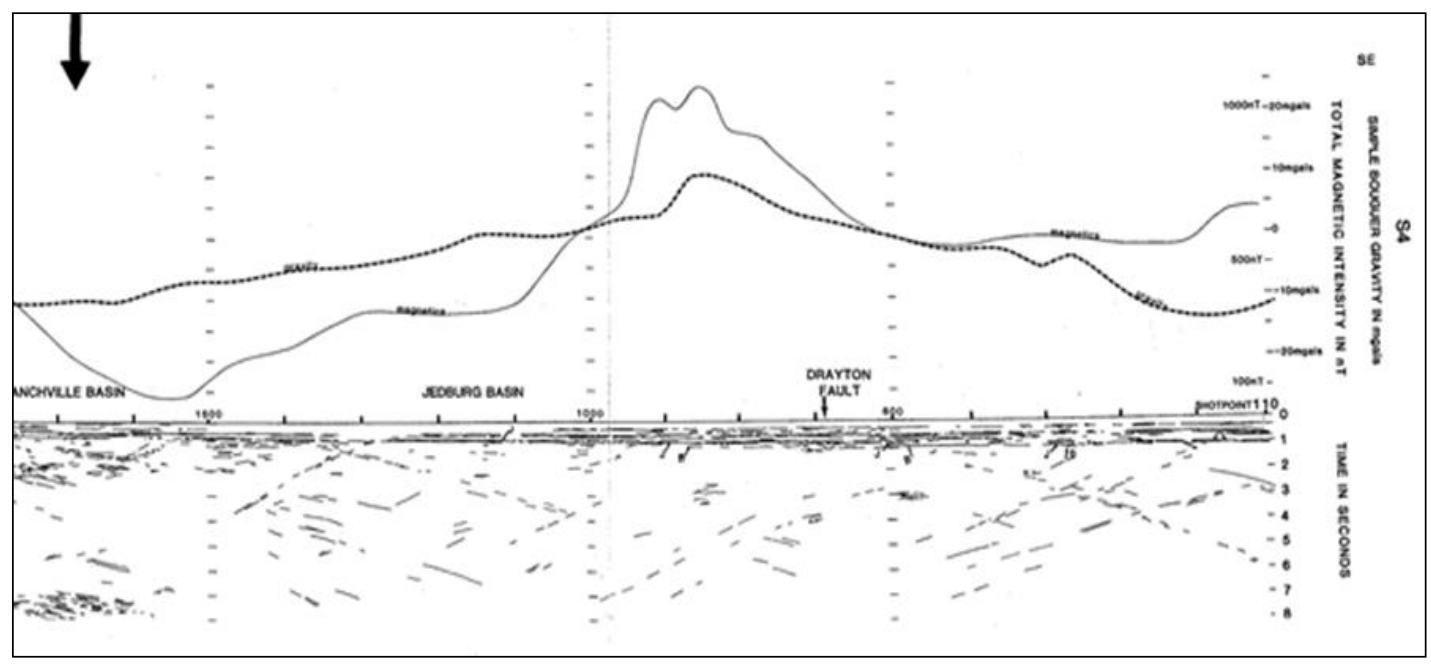

Figure 4.8 Along part of SEISDATA 4 seismic reflection line along profile 1 (Figure 4.9) 


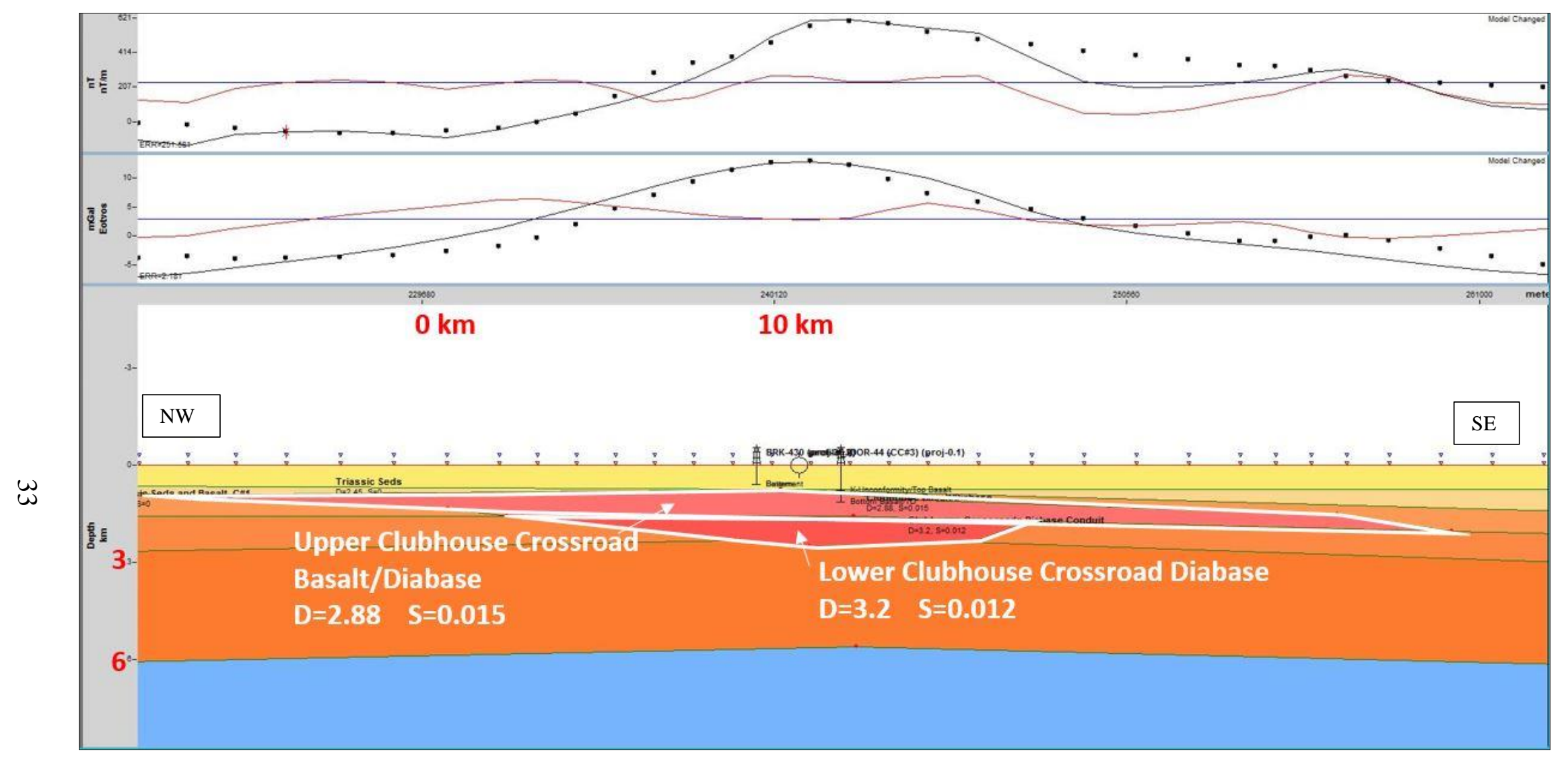

Figure 4.9 Seisdata 4 Profile 1 crossing Clubhouse Crossroads. Dotted black lines: observed gravity below and observed magnetic anomalies above. Solid black lines: calculated. Solid red lines: error. See figures 4.5 and 4.6 for location. 


\section{Profile 2}

The second profile (Figure 4.10) is perpendicular to the first profile SEISDATA 4. The model calculated gravity and magnetic anomalies fit the observed anomalies. The modelled mafic body is up to $2 \mathrm{~km}$ thick and located at $1-3 \mathrm{~km}$ depth. Profile 2 is consistent in density and susceptibility and polygon geometry with profile 1 at their intersection. This is the longest profile extending $\sim 80 \mathrm{~km}$.

\section{Profile 3}

The calculated gravity anomalies for the third profile (Figure 4.11) fit the observed very well; however, remanent magnetization may be required to explain the observed magnetic field. The mafic body is up to $2 \mathrm{~km}$ thick and located at 1-3 $\mathrm{km}$ depth. It extends $40 \mathrm{~km}$ along the profile.

\section{Profile 4}

The model calculated gravity for the fourth profile (Figure 4.12) fits the observed gravity, but remanent magnetization may be required to explain the observed magnetic anomalies. The model mafic body is up to $2 \mathrm{~km}$ thick and located at $1-3 \mathrm{~km}$ depth. The body extends $\sim 30 \mathrm{~km}$ along Profile 4 .

Overall, the four $(4.9,4.10,4.11$, and 4.12) profiles show different trend directions. For example, Profile 1, 3, and 4 locate from northwest to southeast, furthermore, Profile 2 locates from southwest to northeast. On the profiles, the figures are shown to have dotted, black, and red lines. The dotted black lines resemble observed gravity and observed magnetic anomalies. Additionally, solid black lines represent calculated model, whereas solid red lines show the error of the model. 


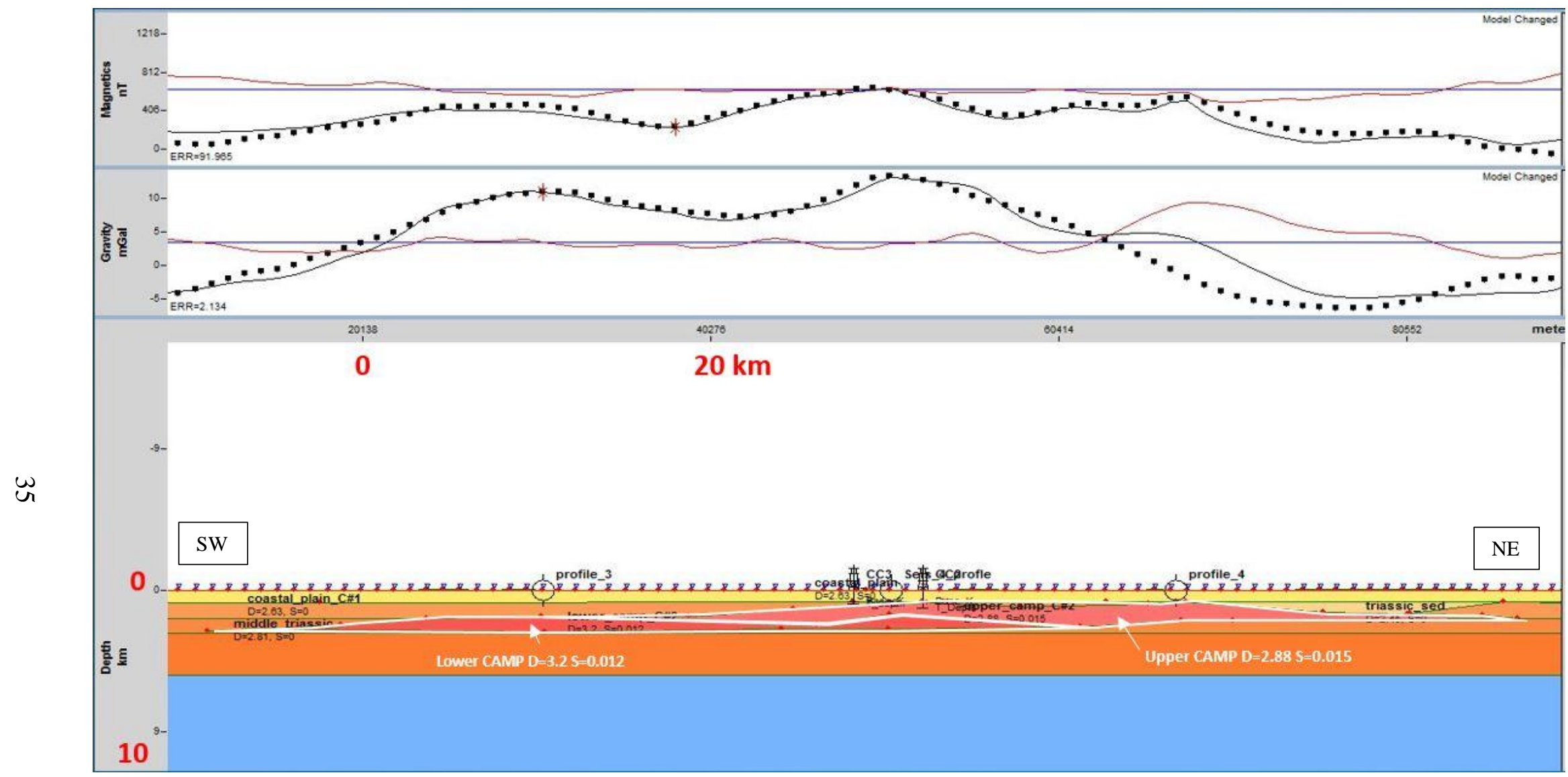

Figure 4.10 Profile 2. Dotted black lines: observed gravity below and observed magnetic anomalies above. Solid black lines: calculated. Solid red lines: error. See figures 4.5 and 4.6 for location. 


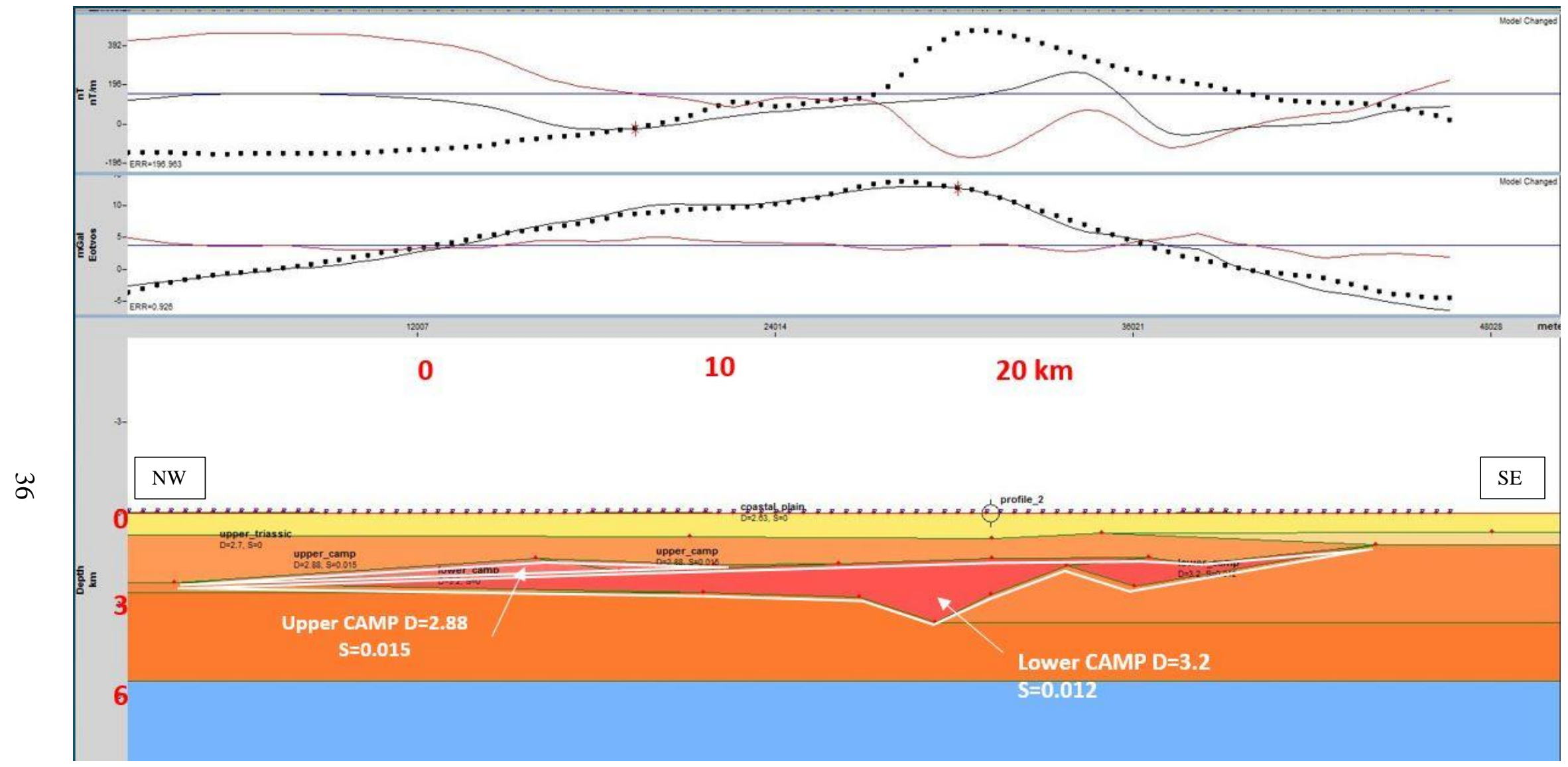

Figure 4.11 Profile 3. Dotted black lines: observed gravity below and observed magnetic anomalies above. Solid black lines: calculated. Solid red lines: error. See figures 4.5 and 4.6 for location. 


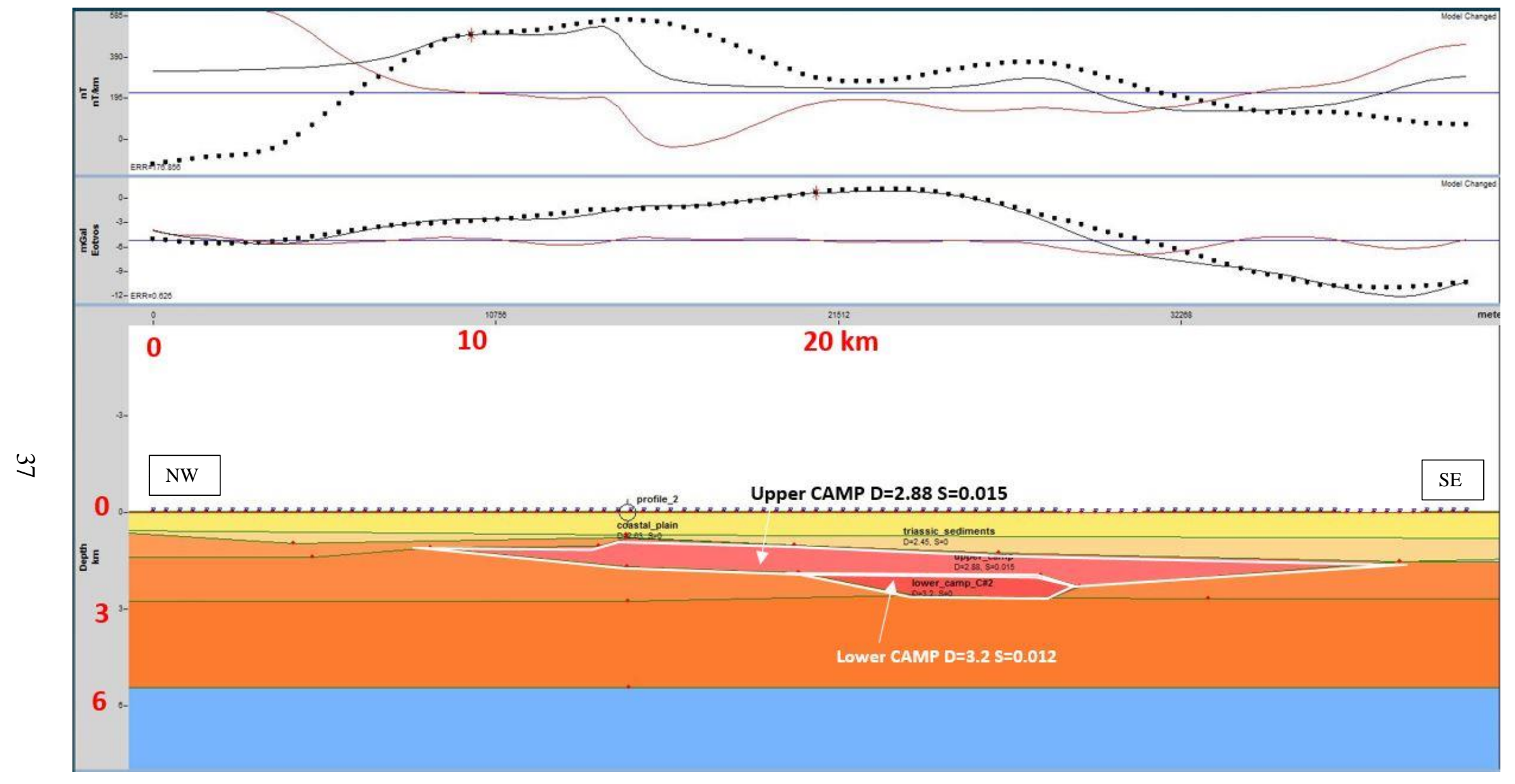

Figure 4.12 Profile 4. Dotted black lines: observed gravity below and observed magnetic anomalies above. Solid black lines: calculated. Solid red lines: error. See figures 4.5 and 4.6 for location. 


\subsection{3-D Inverse Model of Mafic Intrusive Body}

3-D inversion is based on Fast Fourier Transformation (FFT) and space-domain algorithms to calculate the total model response. The forward calculations are based on the frequency domain technique by Parker (1972) and Blakely (1983).

Inversion of the gravity field is more reliable than the magnetic field for prediction of source rock geometries because densities are predictable with small variations vs the variable direction of the magnetic field, order of magnitude variability in magnetic susceptibilities, and uncertainties of remanent versus induced magnetization.

For the GM-SYS 3D inversion model, the first step 1) is to forward model the well-known coastal plain sediment layer (Figure 4.13). 2) With an assumed intrusive/Triassic sediment density contrast, the gravity was then inverted to map the depth of the top of the mafic intrusive/Triassic sediment contact (Figure 4.13). 3) Finally, the residual gravity was inverted to calculate the depth to the base of the mafic intrusive/Lower Triassic contact.

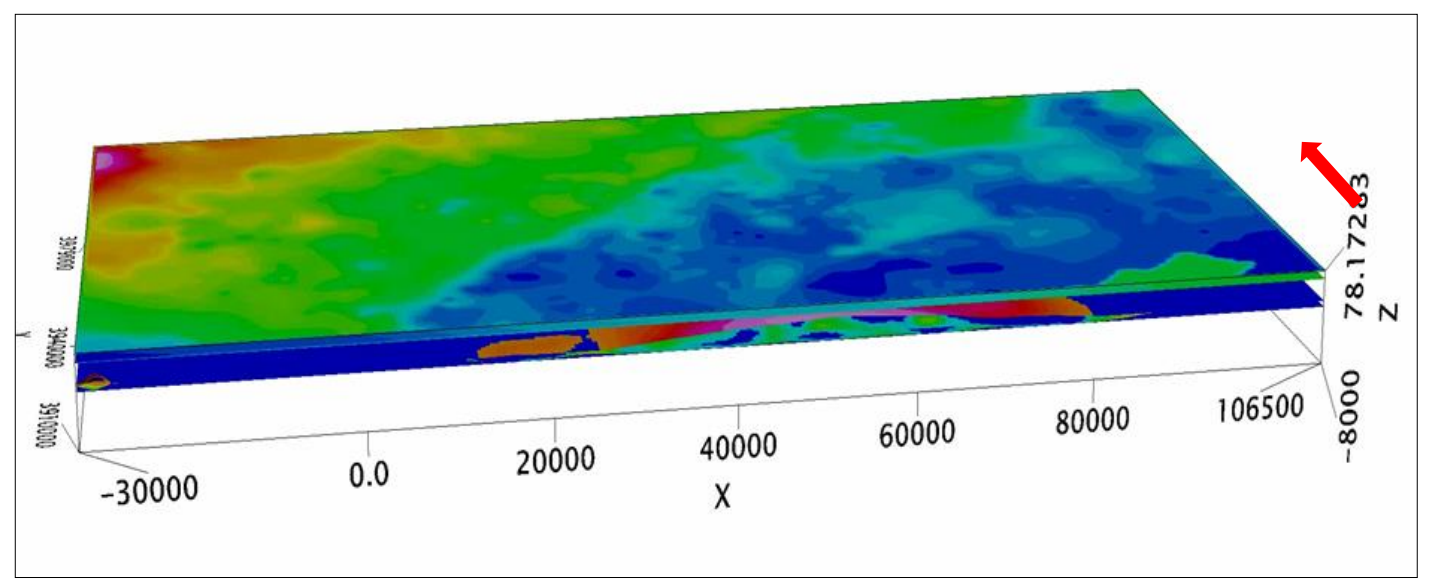

Figure 4.13 Upper and lower bounds of the Coastal Plain sediment layer. Red arrow: north. Distance and depth scales in meters. No vertical exaggeration. 


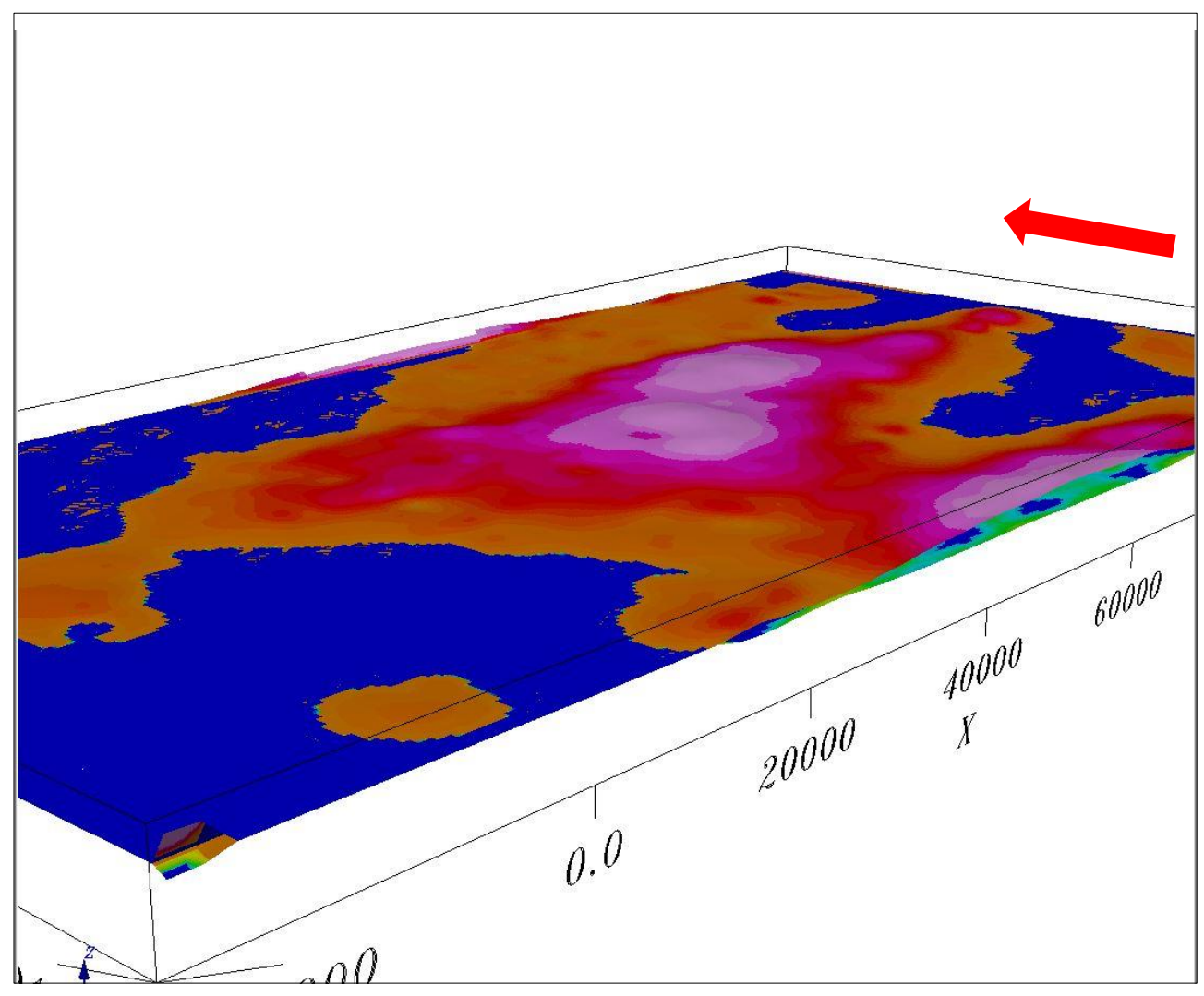

Figure 4.14 Inverted gravity for the top of mafic intrusive. Upper bounds of the Clubhouse Crossroads mafic intrusive. Red arrow: north. Depth scale in meters. No vertical exaggeration.

The 3-D inverse model (Figure 4.16) predicted up to $2 \mathrm{~km}$ thick source geometries. The result is very similar to the 2-D forward model - Profile 2 (Figures 4.10 and 4.16).

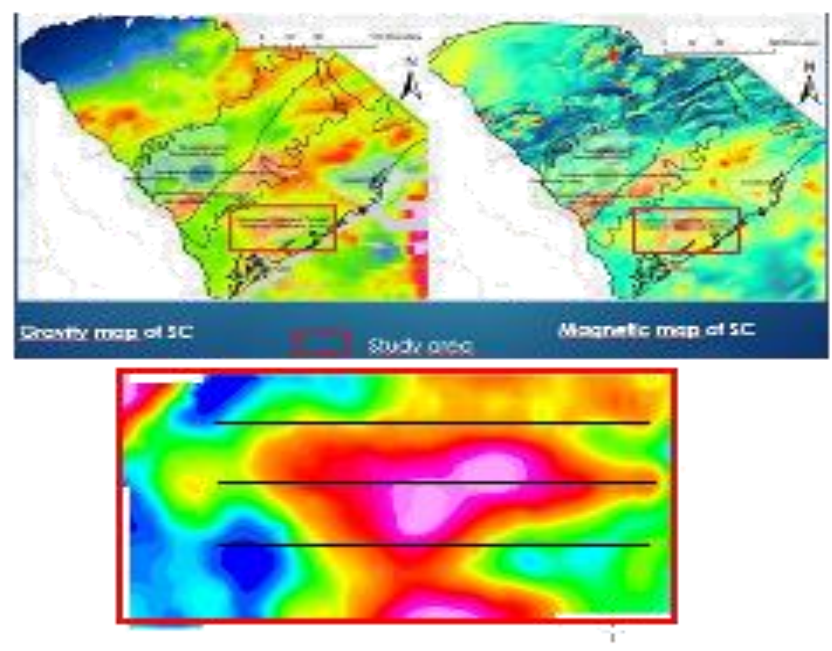

Figure 4.15: Location map of 3-D Gravity Matlab inversion profiles 


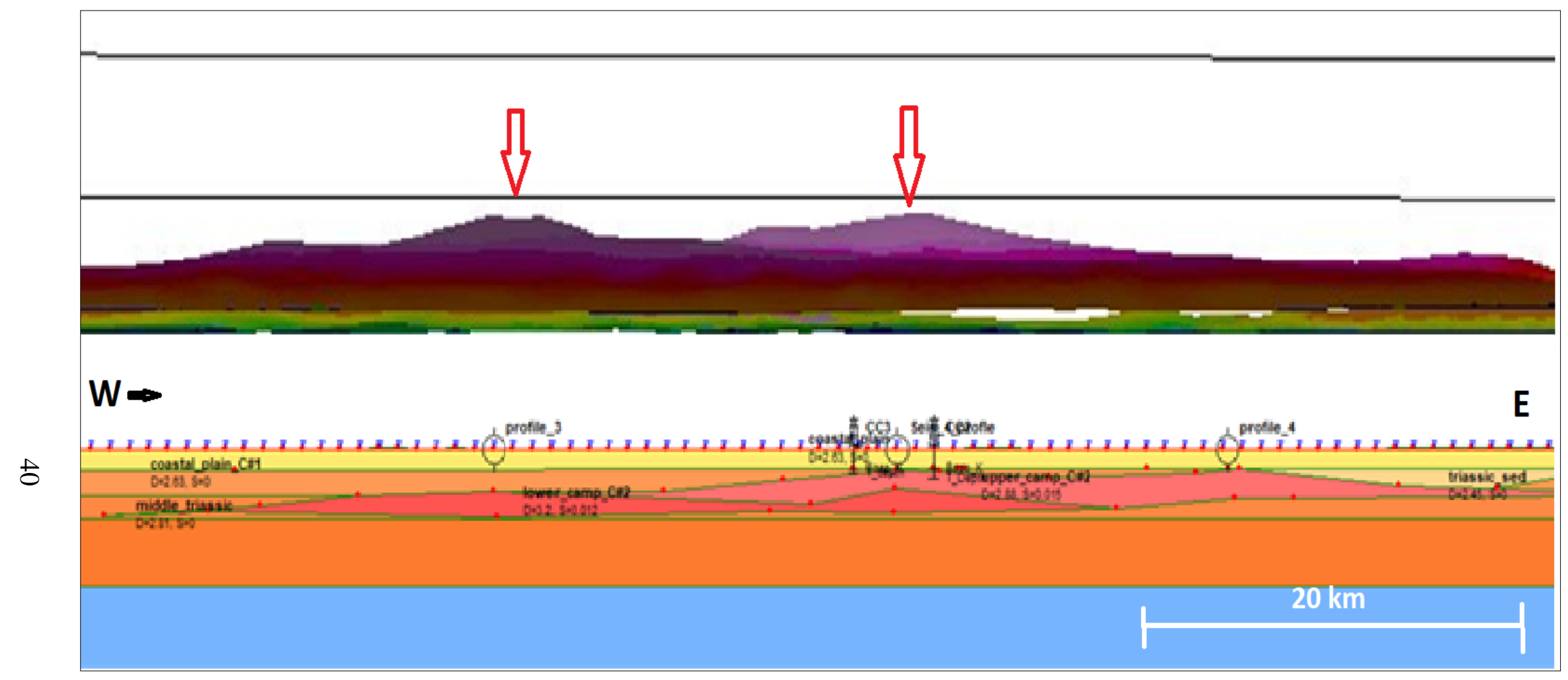

Figure 4.16 3-D inverse model (above) predicts up to $2 \mathrm{~km}$ thick mafic source geometry. Result is similar to 2-D forward model profile 2 (below). No vertical exaggeration. 

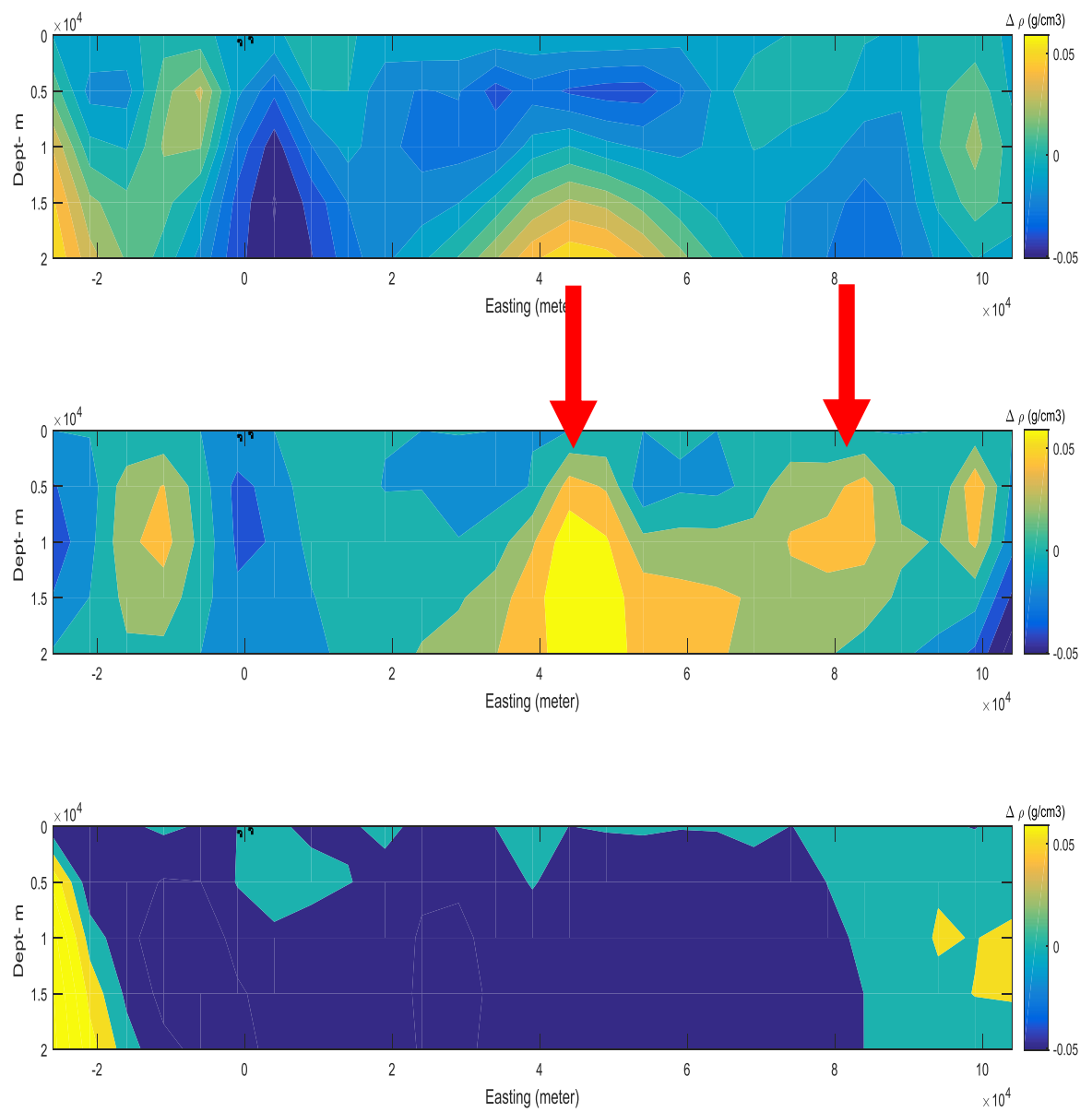

Figure 4.17 3-D Gravity-Fourier Matlab depth inversion. Depth in km. Horizontal scale in units of $10 \mathrm{~km}$. Results are similar to GMSYS 3D inversion, but with lower resolution. The locations of profiles are shown in Figure 4.15.

3-D Gravity-Fourier Matlab depth inversion results (Figure 4.17) are similar to GMSYS 3D inversion results (Figure 4.16), but with lower resolution. Unlike the GMSYS inversion, no coastal plain layer or density contrasts were forward modeled. Arrows point to two high density bodies in the subsurface (Figure 4.16). 


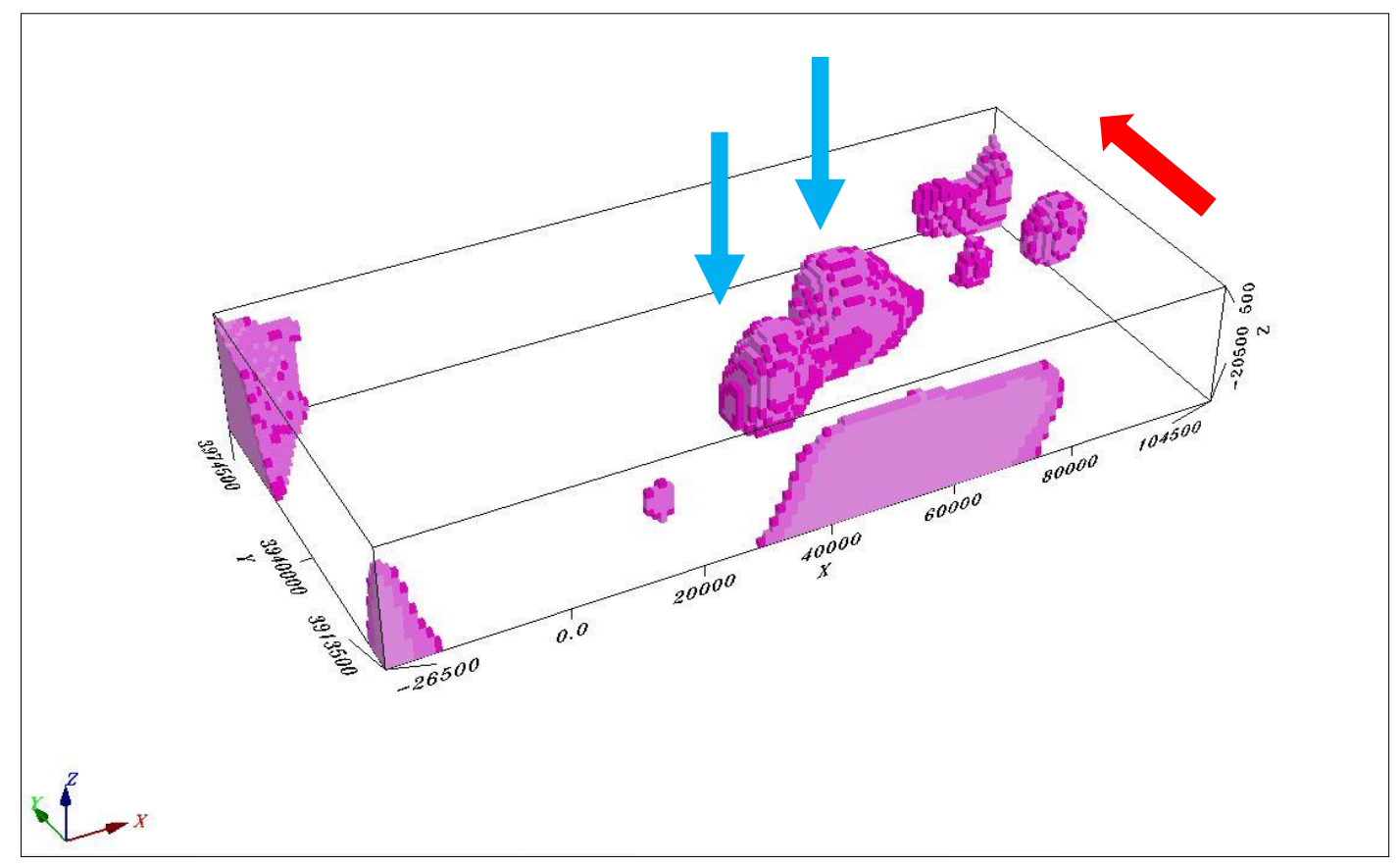

Figure 4.18 Voxi Earth Modeling. Voxi gravity inversion highlights the locations of two dense conduits (blue arrows) for the Clubhouse Crossroads mafic intrusion. Red arrow: North. Scale is in meters. The vertical dimension of the volume is about $20 \mathrm{~km}$. No vertical exaggeration.

The results of Voxi inverse earth modeling are shown in Figure 4.18. No coastal plain layer was modeled and no density contrasts were assumed. The inversion was repeated in an iterative process that minimized the misfit between observed and calculated. All low density areas have been clipped in Fig. 4.18, leaving the locations of two deep dense conduits for the Clubhouse Crossroads mafic body.

\subsection{Is the Clubhouse Crossroads mafic intrusive a laccolith or mafic sill?}

Shallow mafic intrusions often fall into two general categories, mafic sills or laccoliths. Mafic sills are characterized by high aspect ratios, length/thickness (L/T) and shallow emplacement depths (100-3000 m) (Mudge, 1968; Francis, 1982; Leaman, 1975). L/T ratios of large mafic sills ranges from 200 to 2000, corresponding to horizontal dimensions $\mathrm{L} \approx 2$ to $270 \mathrm{~km}$ and thicknesses, $\mathrm{T} \approx 10$ to $600 \mathrm{~m}$. 
Laccoliths are igneous intrusions with a flat floor, steep sides and a slightly arched to flat roof emplaced at crustal depths less than $3 \mathrm{~km}$ (Gilbert, 1877; Johnson and Pollard, 1973; Corry, 1988). They are inferred to grow by upward bending of their wall rocks during vertical inflation of magma after initial emplacement of a bedding parallel sill. Laccolith growth commonly occurs by multiple injection of sheets over timescales ranging from 100 years to 100 kyr (Jackson and Pollard, 1988; de Saint- Blanquat et al., 2006; Michel et al., 2008). Laccoliths range in horizontal dimension, $\mathrm{L} \approx 500 \mathrm{~m}$ to 20 $\mathrm{km}$, and vertical dimension from $\mathrm{T} \approx 15 \mathrm{~m}$ to $2500 \mathrm{~m}$ with a mean aspect ratio $\mathrm{L} / \mathrm{T}$ is $\approx$ 10 , ranging from 1.7 to 45 .

The Clubhouse Crossroads mafic intrusion aspect ratio L/T (length/thickness) averages $35 \mathrm{~km} / 750 \mathrm{~m} \sim 47$. The Clubhouse Crossroads intrusion therefore is a broad laccolith. It may well have begun with the initial emplacement of bedding parallel sills
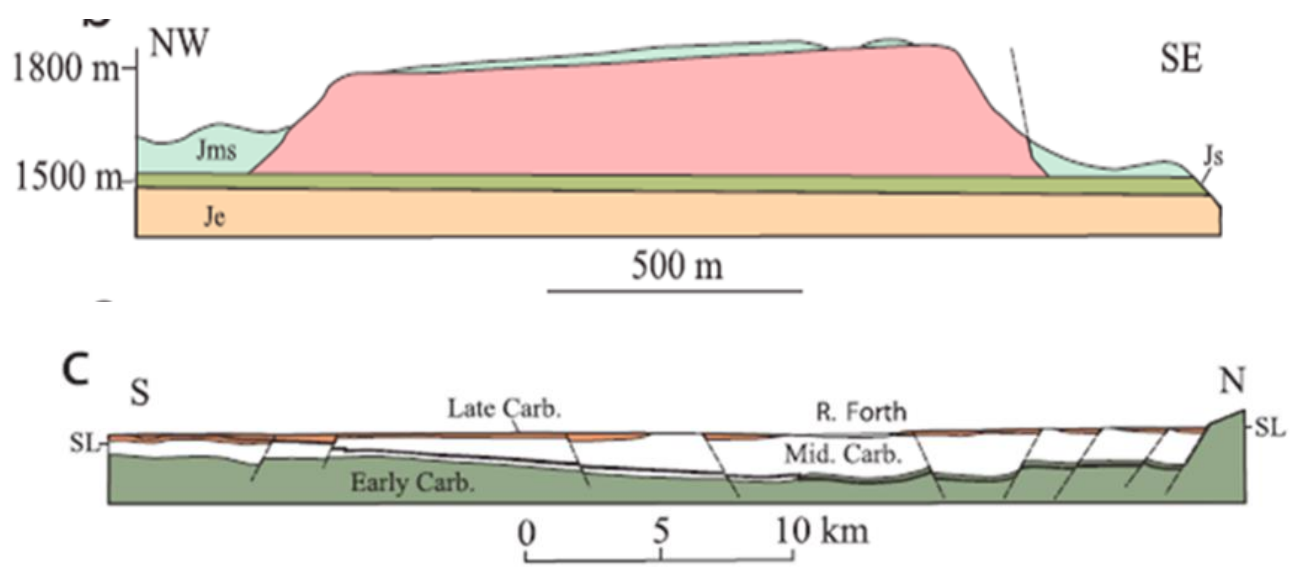

Figure 4.19 Schematic image of laccolith (above) and mafic sill (below) (after Bunger and Cruden, 2011). 


\subsection{Volume Estimation and Density Uncertainties}

Uncertainties regarding the densities of the basalts, diabase, and gabbros in the Clubhouse Crossroads mafic laccolith will introduce errors in the estimation of the total thickness of the intrusion. Basalts, diabase, and gabbros all show similar ranges of densities from $2.7 \mathrm{gm} / \mathrm{cm}^{3}$ to $3.2 \mathrm{gm} / \mathrm{cm}^{3}$ (Tables 4.1 and 4.2). For the 2-D forward models, I assumed a density of $2.88 \mathrm{gm} / \mathrm{cm}^{3}$ for the upper CAMP intrusive and 3.2 $\mathrm{gm} / \mathrm{cm}^{3}$ for the lower CAMP intrusive. This gave a density contrast of $0.18 \mathrm{gm} / \mathrm{cm}^{3}$ between the intrusive and the upper Triassic red beds $\left(2.7 \mathrm{gm} / \mathrm{cm}^{3}\right)$ and a contrast of 0.39 $\mathrm{gm} / \mathrm{cm}^{3}$ with the lower CAMP and the middle Triassic red beds $\left(2.81 \mathrm{gm} / \mathrm{cm}^{3}\right)$. The average density for gabbros, diabase, and gabbros is $2.98 \mathrm{gm} / \mathrm{cm}^{3}$ (Tables 4.1 and 4.2). If we assume the average density of $2.98 \mathrm{gm} / \mathrm{cm}^{3}$ for the mafic intrusives in profile 2 (Figure 4.10), the maximum thickness of the intrusive body would show a minor increase from $1.73 \mathrm{~km}$ to $1.92 \mathrm{~km}$ or about $11 \%$. The minimum density of $2.7 \mathrm{gm} / \mathrm{cm}^{3}$ cannot produce the observed positive gravity anomalies, because it is less than or equal to the density of the surrounding Triassic red beds. If we assume the maximum density of 3.2 $\mathrm{gm} / \mathrm{cm}^{3}$, the thickness of the intrusive would decrease to $0.79 \mathrm{~km}$ (a $46 \%$ decrease). However, a $3.2 \mathrm{gm} / \mathrm{cm} 3$ density for the Clubhouse Crossroads mafic intrusives is unrealistic, so a maximum thickness ranging from 1.73 to $1.92 \mathrm{~km}$ is the most realistic estimate.

Since the three Clubhouse Crossroads wells did not encounter diabase rocks, the top of the intrusive may be deeper than predicted in the models. The deepest well CC3 terminated in Triassic red beds at about 1200 meters depth (Figure 1.3). This therefore is a minimum depth for the top of the laccolith beneath $\mathrm{CC}$. The deeper the center of mass 
of the laccolith, the greater the thickness required to produce the observed positive gravity anomalies. Note that the Summerville oil well just north of the study area (Figure 2.1 red triangle) encountered diabase rocks at a depth of $783 \mathrm{~m}$ (Getz, 2013). The shallow "B" reflector observed nearby at a depth of about $1200 \mathrm{~m}$ and a seismic velocity of 6.4 $\mathrm{km} / \mathrm{sec}$ may correspond to diabase intrusive rocks and not metamorphic basement as previously interpreted.

The volume of the CC laccolith is conservatively estimated as about $\sim 65 \mathrm{~km} \mathrm{x}$ $\sim 20 \mathrm{~km}^{2} 1300 \mathrm{~km}^{3}$ based on the four 2-D forward model profiles and the 3-D inversion (Figure 4.20). The Clubhouse Crossroads Laccolith is over 8 times the volume of the Palisades Sill in the Newark Basin which is $\sim 150 \mathrm{~km}^{3}$ !

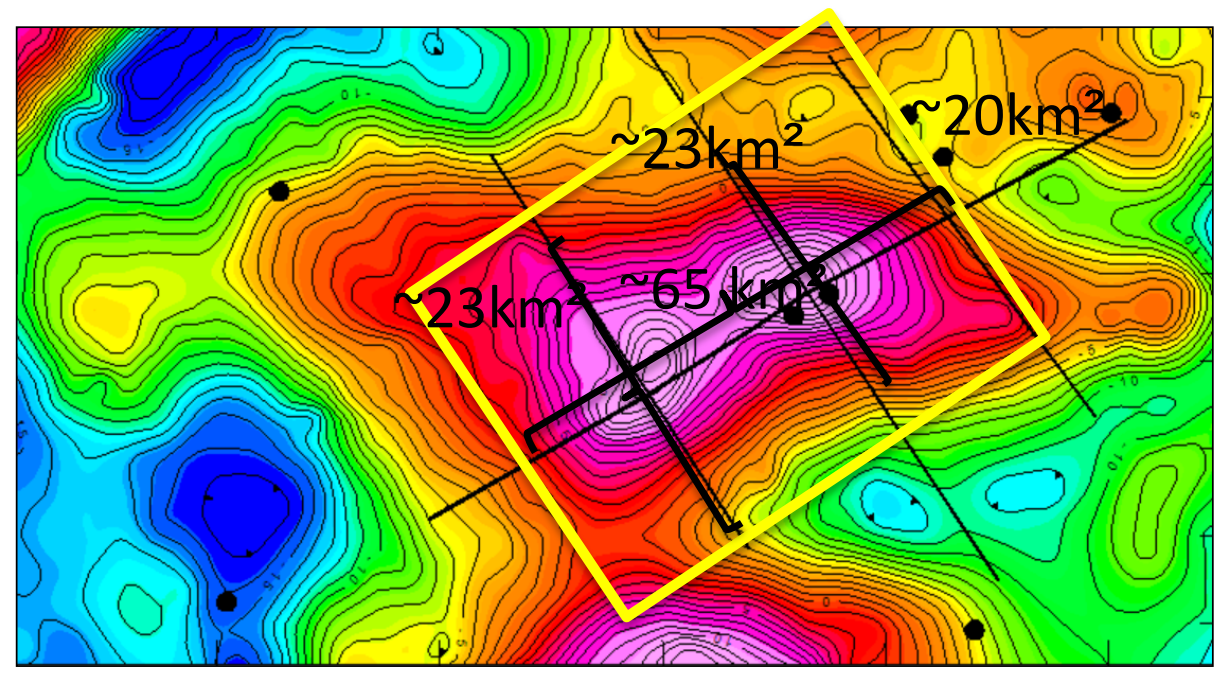

Figure 4.20 The extent of CAMP mafic bodies along with the 2-D forward model profiles. $\sim 65 \mathrm{~km} \mathrm{x} \sim 20 \mathrm{~km}^{2}=\sim 1300 \mathrm{~km}^{3}$.

Getz (2013) estimated the proposed extent of the Clubhouse Crossroad basalt J reflector based on refraction and reflection geometry (Figure 4.21). The proposed basalt area is $~ 3700 \mathrm{~km}^{2}$. For an average flow thickness of $0.3 \mathrm{~km}$, the basalt volume would be 
$\sim 1100 \mathrm{~km}^{3}$. Adding that to the laccolith volume estimated in this study $\sim 1300 \mathrm{~km}^{3}$ yields a total Clubhouse Crossroads volume of $\sim 2400 \mathrm{~km}^{3}$.

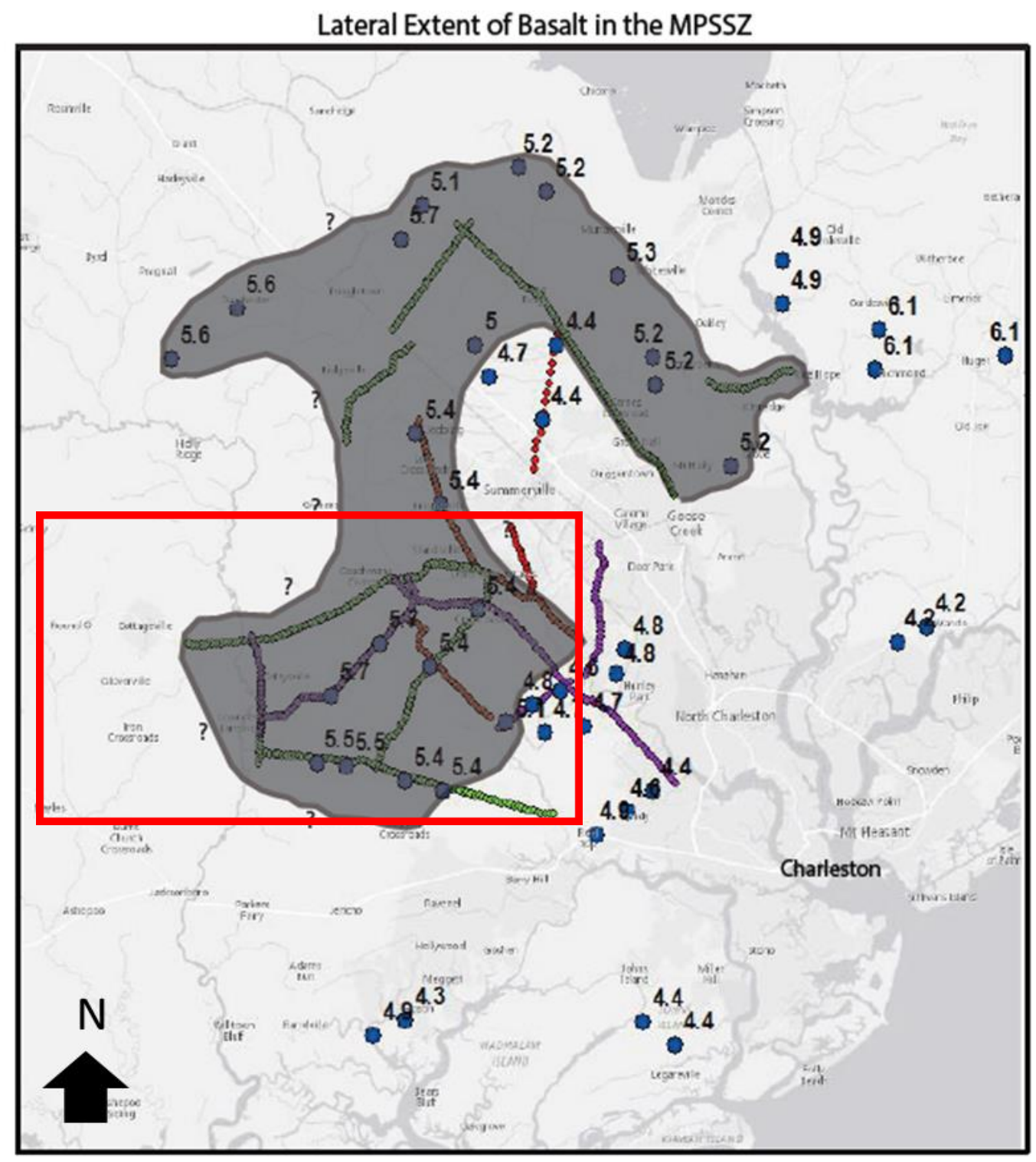

Figure 4.21 Lateral extent of Clubhouse Crossroads basalt (After Getz, 2013). Clubhouse Crossroads mafic intrusive study area shown in red rectangle. 


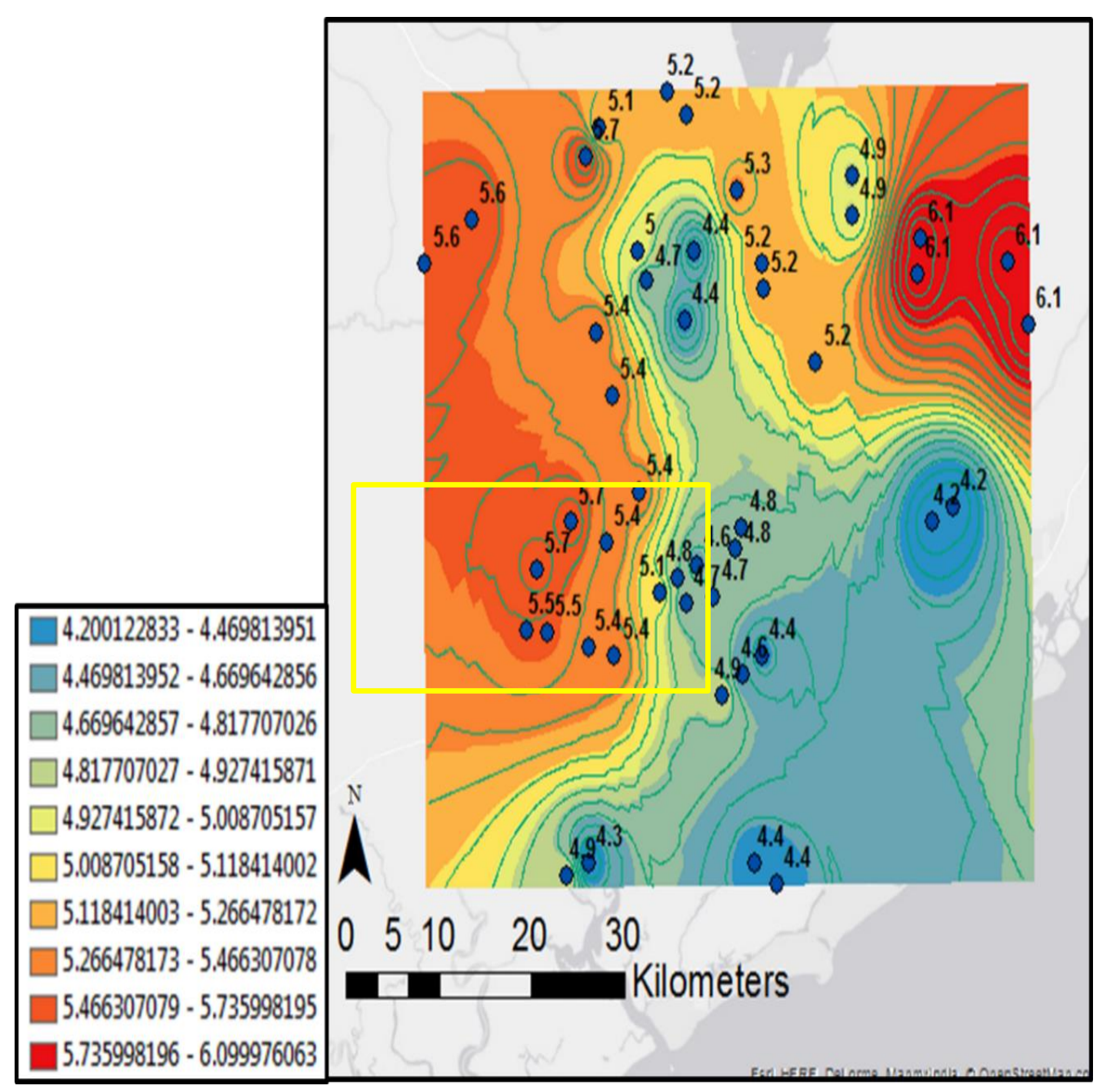

Figure 4.22 Refraction and reflection velocities for the J horizon in the Summerville Clubhouse Crossroads area. Yellow rectangle shows the study area (After Getz, 2013).

From the figure above, it can be seen that the northeast to southwest direction of the study area which is the location of profile 3 is well constrained by seismic reflection and refraction surveys (Figure 4.22). The velocities range between 4.7 and $5.7 \mathrm{~km} / \mathrm{s}$. these velocities in Figure 4.23 show the igneous rock densities. 


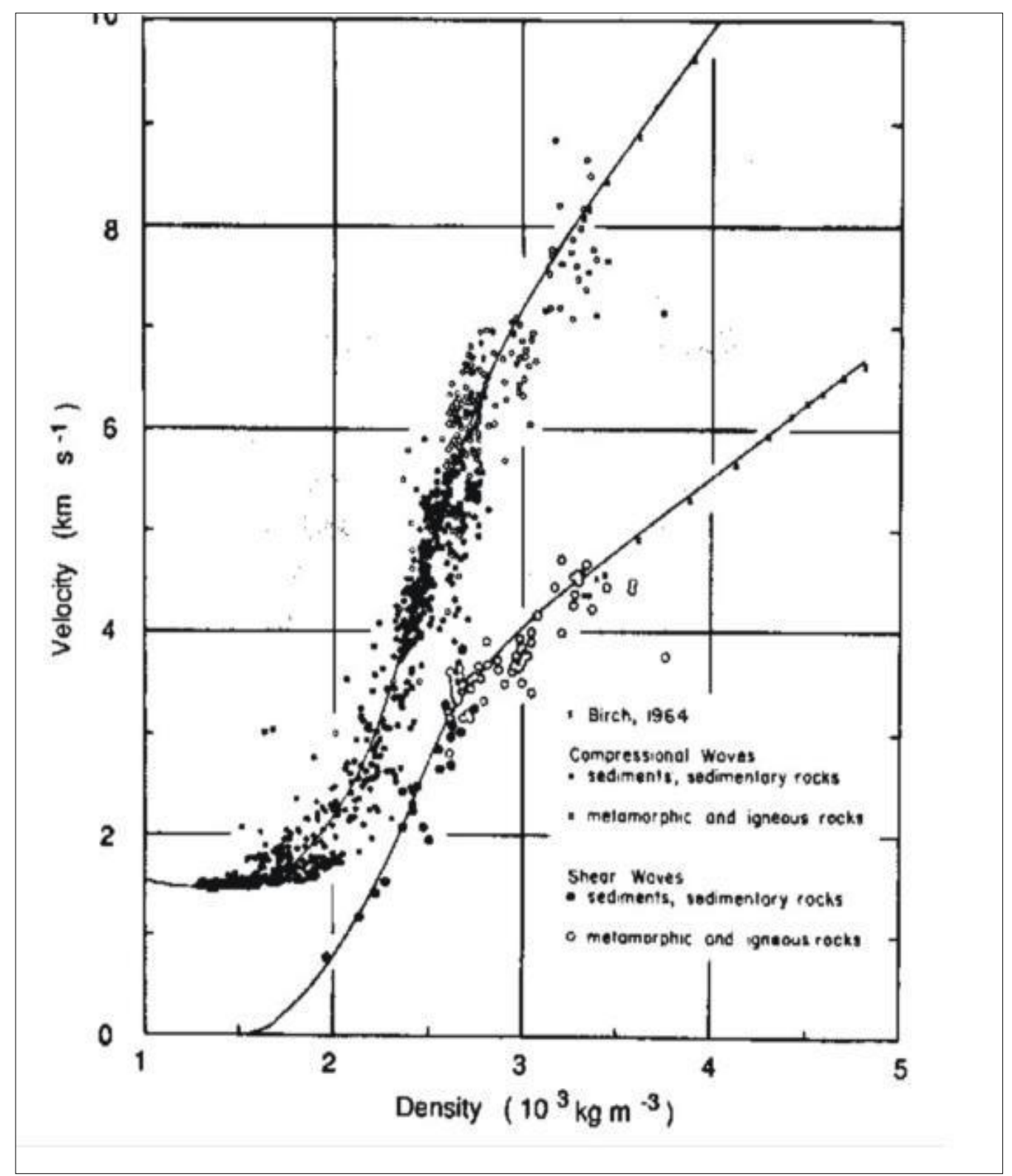

Figure 4.23 Nafe and Drake Velocity to Density Curve (Birch, 1964).

The NE side of the study area is well constrained by seismic reflection and refraction surveys, and J horizon velocities range between 4.7 and $5.7 \mathrm{~km} / \mathrm{s}$. The velocities correlate with igneous rock densities of about $\sim 2.8-2.95 \mathrm{gm} / \mathrm{cm}^{3}$ (Figure 4.23). The velocities correspond with those expected for the basalts encountered in the Clubhouse Crossroads wells. 


\section{CONCLUSIONS}

The Clubhouse Crossroads mafic intrusive is a diabase/gabbro late CAMP or CAMP age laccolith fed by two conduits. Based on density and magnetic forward and inverse models, the laccolith is up to $2 \mathrm{~km}$ thick and extends from 1 to $3 \mathrm{~km}$ depth over $1900 \mathrm{~km} 2$. The volume of the CC laccolith is $\sim 1300 \mathrm{~km} 3$. Previous estimates of CC basalt volumes based solely on drilling and seismic reflection may greatly underestimate the total volumes of CAMP preserved under the Coastal Plain. The Clubhouse Crossroads laccolith may also provide a large potential reservoir for $\mathrm{CO} 2$ sequestration. Further age dating is needed to confirm the ages of the Clubhouse Crossroads basalts as well as the diabase in the Summerville oil well and elsewhere under the coastal plain. This is important to bracket the ages of intrusive mafic activity to relate to either the massive CAMP Large Igneous Province event at 200 Ma or to initial North Atlantic rifting $180 \mathrm{Ma}$. 


\section{REFERENCES}

Austin, J.A., Jr., Stoffa, P.L., Phillips, J.D., Oh, J., Sawyer, D.S., Purdy, G.M., Reiter, E., and Makris, J., 1990, Crustal structure of the Southeast Georgia embaymentCarolina trough: Preliminary results of a composite seismic image of a continental suture(?) and a volcanic passive margin: Geology, v. 18, p. 1023-1027, https://doi.org/10.1130/0091-7613(1990)018<1023:CSOTSG>2.3.CO;2.

Alarifi, S.S., 2017, High Resolution Gravuty, Helicopter, Magnetic, and Electromagnetic Study, Haile Gold Mine, South Carolina, (Master's thesis).

Ansari, A.H., Alamdar, K., 2009, Reduction to the Pole of Magnetic Anomalies Using Analytic Signal, World Applied Sciences Journal 7,1818-4952.

Beck, M.E., 1965, Paleomagnetic and geologic implications of magnetic properties of the Triassic diabase of southern Pennsylvania: Journal of Geophysical Research, v. 70, p. 2845-2856.

Beutel, E.K., Nomade, S., Fronabarger, A.K., Renne, P.R., 2005. Pangea's complex breakup: a new rapidly changing stress field model. Earth and Planetary Science Letters, 236, 471-485.

Birch, F. 1964, Density and composition of mantle and core, Journal of Geophysical Research, Volume 69, issue 20, p. 4377-4388.

Bunger, A. and Cruden A.R., 2011. Modeling the growth of laccoliths and large mafic sills: Role of magma body forces, Journal of Geophys. Research Atmospheres, VOL. 116, B02203, doi:10.1029/2010JB007648, 2011

Carmichael, R., Klein, C., 2018, Rock Geology, Encyclopedia Britannica.

Callegaro, S., Marzoli, A., Bertrand, H., Chiaradia, M., Reisberg, L., Meyzen, C., Bellieni, G., Weems, R.M., 2013, Upper and Lower Crust Recycling in the Source of CAMP Basaltic Dykes from Southeastern North America, Earth and Planetary Science Letters.

Chowns, T.M., and Williams, C.T., 1983, Pre-Cretaceous rocks beneath the Georgia Coastal Plain - Regional implications, in Gohn, G.S., ed., Studies related to the Charleston, South Carolina, earthquake of 1886-Tectonics and seismicity: U.S. Geological Survey Professional Paper 1313-L, p. L1-L42. 
Cumbest, R. J., Price, V., and Anderson, E.E., 1992, Gravity and magnetic modeling of the Dunbarton Triassic basin, South Carolina: Southeastern Geology, v. 33, p. 3751.

Christensen, N.I., 1989, Pore pressure, seismic velocities, and crustal structure, in Pakiser, L.C., and Mooney, W.D., eds., Geophysical framework of the continental United States: Geological Society of America Memoir 172, p. 783-798.

Connor, C., Connor, L., Gravity Density Lecture Notes, Potential Fields Geophysics, University of South Florida.

Corry, C. E.,1988, Laccoliths: Mechanics of emplacement and growth, Spec. Pap. Geol. Soc. Am., 210, 110 pp.

Coruh, Cahit. Costain, J. K., Behrendt, J. H., Hamilton, R. A., 1982, Mesozoic Faulting in the Charleston, South Carolina Region: New Evidence from Seismic Reflection Data. Unpublished.

Cumbest, R.J., Price, V., Anderson, E.E., 1992, Gravity and magnetic modeling of the Dunbarton Triassic basin, South Carolina: Southeastern Geology, v. 33, no. 1, p. $37-51$.

Daniels, D. L., Zietz, I., and Popenoe, P., 1983, Distribution of subsurface lower Mesozoic rocks in the southeastern United States as interpreted from regional aeromagnetic and gravity maps, in Gohn, G. S., ed., Studies related to the Charleston, South Carolina, earthquake of 1886-Tectonics and seismicity: U.S. Geological Survey Professional Paper 1313, p. 1C1-K24.

Davis, J.K., Bécel, A., and Buck, W.R., 2018, Estimating emplacement rates for seawarddipping reflectors associated with the U.S. East Coast Magnetic Anomaly: Geophysical Journal International, v. 215, p. 1594-1603, http://doi.org/ 10.1093/gji/ggy360.

de Saint Blanquat, M., G. Habert, E. Horsman, S. S. Morgan, B. Tikoff, P. Launeau, and G. Gleizes (2006), Mechanisms and duration of nontectonically assisted magma emplacement in the upper crust: The Black Mesa pluton, Henry Mountains, Utah, Tectonophysics, 428, 1-31, doi:10.1016/j.tecto.2006.07.014.

Dobrin, M.B., and Savit, C.H., 1988, Introduction to Geophysical Prospecting (4th ed.), New York, McGraw-Hill.

Duff, P.D., and Kellogg, J.N., 2019, The Brunswick magnetic anomaly: Geophysical Signature and geologic source: Geology, v. 47, p. 1-4, Data and Method Supplement Appendix, https:// doi .org /10 .1130/G45462.1.

Duff, P.D., and Kellogg, J.N., 2017, Reinterpretation of adcoh and cocorp seismic 
reflection data with constraints from detailed forward modeling of potential field data - Implications for Laurentia-Peri-Gondwana suture: Tectonophysics, v. 712713, p. 426-437, http://dx.doi.org/10.1016/j.tecto.2017.06.002.

Duff, P.D., Kellogg J., Howard, S., Horton, J.W., 2014, Imaging granites, igneous plutons and faults associated with continental collision and rifting using potential field, seismic, and well data, South Georgia rift basin and vicinity, Georgia: GSA Abstracts with Programs, Vol. 46, No. 3.

Fairhead, J. D., Salem, A., \& Blakely, R. J. (2010, April). Continental to basin scale mapping of basement depth and structure using the tilt-depth method. In EGM 2010 International Workshop.Francis, E. H.,1982, Magma and sediment I Emplacement mechanism of late Carboniferous tholeiite sills in northern Britain, J. Geol. Soc., 139, 1-20, doi:10.1144/gsjgs.139.1.0001.

Getz, J.E., 2017. The Summerville Formation: Evidence for a sub-horizontal stratigraphic sequence below the Post-rift Unconformity in the Middleton Place Summerville Seismic Zone (Masters Research), University of South Carolina, U.S.A.

Gilbert, G. K.,1877, Geology of the Henry Mountains, U. S. Geographical and Geological Survey of the Rocky Mountain Region, 170 pp., Washington, Govt. Print. Off., Washington, D. C.

Ginzburg, A., Mooney, W.D., Walter, A.W., Lutter, W.J., Healy, J.H., 1983, Deep structure of the Mississippi embayment: AAPG Bulletin, v. 67, no. 11, p. 20312046.

Hames, W. E., Ruppel, C., Renne, P.R., 2000, New evidence for geologically instantaneous emplacement of earliest jurassic central atlantic magmatic province basalts on the North american margin,Geology, v. 28, no. 9, p.859-862.

Heffner, D. M., 2013, Tectonics of the South Georgia Rift. (Doctoral dissertation). Retrieved from http://scholarcommons.sc.edu/etd/1330.

Heffner, D. M., Knapp, J. H., Akintunde, O.M, Knapp, C., 2012, preserved extend of Jurassic flood basalt in the South Georgia Rift: A New interpretation of the $\mathrm{J}$ horizon, Geological Society of America, v. 40, no. 2, p. 167-170.

Holbrook, W.S., Reiter, E.C., Purdy, G.M., Sawyer, D., Stoffa, P.L., Austin, J.A., Jr., Oh, J., and Makris, J., 1994, Deep structure of the U.S. Atlantic continental margin, offshore South Carolina, from coincident ocean bottom and multichannel seismic data: Journal of Geophysical Research, v. 99, p. 9155-9178, https://doi.org/10.1029/93JB01821. 
Jackson, M. D., and D. D. Pollard,1988, The laccolith- stock controversy: New results from the southern Henry Mountains, Utah, Geol. Soc. Am. Bull., 100, 117-139, doi:10.1130/0016-7606(1988)100<0117:TLSCNR> 2.3.CO;2.

Johnson, A. M., and D. D. Pollard, 1973, Mechanisms of some laccolithic intrusions in the Henry Mountains, Utah, Part I: Field observations, Tectonophysics, 18(3- 4), 261-309, doi:10.1016/0040-1951(73)90050-4.

Leaman, D. E.,1975, Form, mechanism and control of dolerite intrusion near Hobart, Tasmania, J. Geol. Soc. Aust., 22, 175-186.

Li, Y., Oldenburg, D. W., 1998,3-D inversion of gravity data, Geophysics, Vol.63, No.1, p.109-119.

Luetgert, J.H., Benz, H.M., Madabhushi, S., 1994, Crustal structure beneath the Atlanticcoastal plain of South Carolina: Seismological Research Letters, v. 65, p. 180-191, http://doi.org/10.1785/gssrl.65.2.180.

Ludwig, W.J., Nafe, J.E., and Drake, C.L., 1970, Seismic refraction, in The Sea, A.E. Maxwell (Editor), Vol. 4, Wiley-Interscience, New York, p. 53-84.

MacLeod, I.N., Jones, K., and Dai, T.F., 1993, 3-D analytic signal in the interpretation of total magnetic field data at low magnetic latitudes: Exploration Geophysics, v. 24, p. 679-687.

Marzoli, A., Renne, P.R., Piccirillo, E.M., Ernesto, M., Bellieni, G., De Min, A.,1999 Extensive 200-Million-Year-Old Continental Basalts of the Central Atlantic Magmatic Province, Reports, vol.284, p.616-618.

McBride, J.H., Nelson, K.D., Brown L.D., 1987, Early mesozoic basin structure and tectonics of the Southeastern United States as revealed from COCORP reflection data and the relation to Atlantic rifting, Canadian Society of Petroleum Geologist, Memoir 12, p.173-184.

McBride J.H., Nelson, K.D., Brown, L.D.,1989, Evidence and Implications of an Extensive Early Mesozoic rift and basalt/diabase Sequence the Southeast Coastal Plain, Geological Society of America Bulletin, v. 101, p. 512-520.

McHone, J.G., 2000, Non-plume magmatism and rifting during the opening of the central Atlantic Ocean, Tectonophysics, 316(3-4) 9.

McHone, J.G., Anderson, D.L., Beutel, E.K., Fialko, Y.A., 2005. Giant dikes, rifts, flood basalts, and plate tectonics: A contention of mantle models. In: Foulger, G.R., Natland, J.H., Presnall, D.C., Anderson, D.L. (Eds.), Plates, Plumes, and Paradigms: Geological Society of America Special Paper, 388, pp. 401-420. 
Michel, J., L. Baumgartner, B. Putlitz, U. Schaltegger, and M. Ovtcharova (2008), Incremental growth of the Patagonian Torres del Paine laccolith over 90 k.y., Geology, 36(6), 459-462, doi:10.1130/G24546A.1.

Mousa, A., Al-Rahim, A., 2016, International Journal of Engineering Research and Science (IJOER), Vol-12, Issue 12, 2395-6992.

Mudge, M. R. (1968), Depth control of some concordant intrusions, Geol. Soc. Am. Bull., 79, 315-332, doi:10.1130/0016-7606(1968)79[315: DCOSCI]2.0.CO;2.

Nabighian, M.N., 1972, The Analytic Signal of the Two-Dimensional Magnetic Bodies With Polygonal Cross-Section: Its Properties and Use for Automated Anomaly Interpretation, Geophysics, Volume 37.

Nomade, S., Knight, K.B., Beutel, E., Renne, P.R., Verati, C., Feraud, G., Marzoli, A., Youbi, N., Bertrabd, H.,2006, Chronology of the Central Atlantic Magmatic Province: İmplcations for the Central Atlantic Rifting Processes and the TriassicJurassic Biotic Crisis, Science Direct Palaeogeography, Paleoclimatology, Palaeoecology.

Olsen, P.E., 1997, Stratigraphic record of the early Mesozoic breakup of Pangea in the Laurasia-Gondwana rift system. Annu. Rev. Earth Planet. Sci., 25(1), 337-401.

Oruc, B. Pure Appl. Geophys., (2011) 168: 1769. https://doi.org/10.1007/s00024-010$\underline{0211-0 .}$

Parker, P., M., 2002, Newton's Law of Universal Gravitation, Department of Physics, Michigan State University, MISN-0-101.

Parker, R. L., 1972, The Rapid Calculation of Potential Anomalies, Geophys. J. R. astr. Soc., 31, 447-445.

Phillips, J.D. 1983, Paleomagnetic investigations of the Clubhouse Crossroads basalt in Gohn, G.S., ed., Studies related to the Charleston, South Carolina, earthquake of 1886-Tectonics and seismicity: U.S. Geological Survey Professional Paper 1313-L, p. C1-C18.

Ragland, P .C., Hatcher Jr., R. D., Whittington, D., 1983, Juxtaposed Mesozoic Diabase Dike Sets from the Carolinas: A preliminary assessment, Geology v.11, p. 394399.

Salem, A., William, S., Fairhead, J. D. Ravat, D., and Smith, R., 2007. Tilt Depth method, A simple depth estimation method using first order magnetic derivatives, The leading Edge, 26, 1502-1505.

Salem, A., 2005, Interpretation of Magnetic Data Using Analytic Signal Derivatives, 
Airbone Geophysics Department, Nuclear Materials Authority of Egypt, Geophysical Prospecting, 53, 75-82.

Sharma, P.V., 1997, Environmental and Engineering Geophysics, Cambridge University Press, 1. Title, pg. 17, 0521572401.

Schilt, F. S., Brown, L. D., Oliver, J. E., and Kaufman, Sidney, 1983, Subsurface structure near Charleston, South Carolina; Results of COCORP reflection profiling in the Atlantic Coastal Plain, in Gohn, G. S., ed., Studies related to the Charleston, South Carolina, earthquake of 1886-Tectonics and seismicity: U.S. Geological Survey Professional Paper 1313, p. H1-H19.

Sumner, J.R., 1977, Geophysical investigation of the structural framework of the Newark-Gettysburg Triassic basin, Pennsylvania: Geological Society of America Bulletin, v. 88, p. 935-942, http://doi.org/10.1130/0016-7606(1977)88 2.0.CO;2.

Talwani, M., Worzel, J.L., Landisman, M.G., 1959, Rapid gravity computations for twodimensional bodies with application to the mendocino submarine fracture zone pacific ocean: Journal of Geophysical Research, v.64, no. 1, p. 49-59.

Talwani, M., Heirtzler, J.R., 1964, Computation of magnetic anomalies caused by twodimensional bodies of arbitrary shape, in Parks, G. A., Ed., Computers in the mineral industries, Part 1: Stanford Univ. Publ., Geological Sciences, 9, 464-480.

Telford, W. M., Geldart, L.P., Sheriff, R.E., 1990. Applied Geophysics, Cambridge University Press, $2^{\text {nd }}$ Edition, 0-521-32693-1.

Verduzco, B., Fairhead, J. D., Green, C. M. and MacKenzie, C., 2004 New insights into magnetic derivatives for structural mapping, The Leading Edge, 23, 116-119.

Verlinde, E., 2011, On the origin of gravity and laws of Newton, Publication for SISSA, Institute for Theoretical Physics, University of Amsterdam, 029.

Warren, D.H., Healy, J.H., Jackson, W.H., 1966, Crustal seismic measurements in southern Mississippi: Journal of Geophysical Research, v. 71, no. 14, p. 34373456.

Whalen, L., E. Gazel, C. Vidito, J. Puffer, M. Bizimis, W. Henika, and M. J. Caddick 2015, Supercontinental inheritance and its influence on supercontinental breakup: The Central Atlantic Magmatic Province and the breakup of Pangea, Geochem. Geophys. Geosyst., 16, 3532-3554, doi:10.1002/2015GC005885.

Yantis, B. R., Costain, J. K., and Ackermann, H. D., 1983, A reflection seismic study near Charleston, South Carolina, in Gohn, G. S., ed., Studies related to the Charleston, South Carolina, earthquake of 1886-Tectonics and seismicity: U.S. Geological Survey Professional Paper 1313, p. G1-G20. 